Old Dominion University

ODU Digital Commons

OEAS Faculty Publications

Ocean, Earth \& Atmospheric Sciences

2008

\title{
Rates of Carbonate Dissolution in Permeable Sediments Estimated From Porewater Profiles: The Role of Sea Grasses
}

\author{
David J. Burdige \\ Old Dominion University, dburdige@odu.edu
}

Richard C.Zimmerman

Old Dominion University, rzimmerm@odu.edu

Xinping $\mathrm{Hu}$

Follow this and additional works at: https://digitalcommons.odu.edu/oeas_fac_pubs

Part of the Marine Biology Commons, Oceanography Commons, and the Sedimentology Commons

\section{Repository Citation}

Burdige, David J.; Zimmerman, Richard C.; and Hu, Xinping, "Rates of Carbonate Dissolution in Permeable Sediments Estimated From Porewater Profiles: The Role of Sea Grasses" (2008). OEAS Faculty Publications. 67.

https://digitalcommons.odu.edu/oeas_fac_pubs/67

\section{Original Publication Citation}

Burdige, D.J., Zimmerman, R.C., \& Hu, X.P. (2008). Rates of carbonate dissolution in permeable sediments estimated from pore-water profiles: The role of sea grasses. Limnology and Oceanography, 53(2), 549-565. doi: 10.4319/lo.2008.53.2.0549

This Article is brought to you for free and open access by the Ocean, Earth \& Atmospheric Sciences at ODU Digital Commons. It has been accepted for inclusion in OEAS Faculty Publications by an authorized administrator of ODU Digital Commons. For more information, please contact digitalcommons@odu.edu. 


\title{
Rates of carbonate dissolution in permeable sediments estimated from pore-water profiles: The role of sea grasses
}

\author{
David J. Burdige, ${ }^{1}$ Richard C. Zimmerman, and Xinping $H u^{2}$ \\ Department of Ocean, Earth and Atmospheric Sciences, Old Dominion University, Norfolk, Virginia 23529
}

\begin{abstract}
In this study we estimate sediment carbonate dissolution rates for sandy sea grass sediments on the Bahamas Bank using an inverse pore-water advection/diffusion/reaction model constrained by field observations. This model accounts for sea grass $\mathrm{O}_{2}$ input to these sediments, and also parameterizes pore-water advection through these permeable sediments as a nonlocal exchange process. The resulting rates of carbonate dissolution are positively correlated with sea grass density, and are comparable with previous rate estimates for Florida Bay sediments. In contrast, the advective uptake of $\mathrm{O}_{2}$ by these sediments decreased with increasing sea grass density. This suggests that the competing interplay between bottom-water flow, near-seabed pressure gradients, and the presence of a sea grass canopy is important in controlling this type of sediment oxygen uptake. When the carbonate dissolution rates estimated here are examined in the context of carbonate budgets for shallow-water carbonate platforms systems, they suggest that carbonate dissolution may be a significant loss term in these budgets. Sea grass-mediated carbonate dissolution may also exert a negative feedback on rising atmospheric $\mathrm{CO}_{2}$, although the magnitude of this effect remains to be quantified.
\end{abstract}

In shallow water environments such as the Bahamas Bank the production of carbonate sediments (both sands and muds) occurs by biogenic and inorganic precipitation (Macintyre and Reid 1992; Milliman 1993; Broecker et al. 2001; and others). Once formed, this material can be altered by reactions in the water column (e.g., during resuspension), on the sediment surface, and during burial (also see Winland and Matthews 1974; Melim et al. 2002; Morse 2003).

The ultimate fate of this carbonate (i.e., net accumulation vs. export or dissolution) is, however, not well constrained. In particular, carbonate dissolution is a poorly quantified component of shallow-water bank and shelf carbonate budgets (Milliman 1993), although studies conducted in Florida Bay (U.S.A.) suggest that carbonate dissolution may be comparable in magnitude with the assumed offshore export of carbonate from such shallowwater environments (Walter and Burton 1990; Ku et al. 1999; Yates and Halley 2006). The role of shallow-water sediment carbonate dissolution as a sink for rising levels of

\footnotetext{
${ }^{1}$ Corresponding author (dburdige@odu.edu).

${ }^{2}$ Current address: Department of Marine Sciences, University of Georgia, Athens, Georgia 30602.

Acknowledgments

We thank the following people for assistance in the field and in the lab: Kim Krecek, Michelle McElvaine, Scott Kline, Jean-Paul Simjouw, Kip Gardner, Lisa Drake, Laura Bodensteiner, and Peter Sandhei. We also thank Heidi Dierssen for providing us with unpublished results from her remote sensing analyses of images of the Bahamas Bank. Finally, we thank two anonymous reviewers for useful comments on the first version of this manuscript. The staff at the Caribbean Marine Research Center (CMRC) provided us with superb logistic support and made our stays at Lee Stocking Island extremely productive.

Funding for this work was provided by NSF (Chemical Oceanography Program) and CMRC (through the NOAA-NURP program).
}

atmospheric $\mathrm{CO}_{2}$ has also previously been examined by Andersson et al. (2003), although these authors concluded that this process represents an insignificant buffer to this $\mathrm{CO}_{2}$ increase.

Past studies have described the occurrence of carbonate dissolution in shallow-water sediments using chemical, isotopic, and mineralogical techniques (e.g., Berner 1966; Moulin et al. 1985; Morse et al. 1987). However, rates of carbonate dissolution in the context of other sediment biogeochemical processes are less well quantified (also see Morse et al. 2003 for a review). Furthermore, previous attempts to generate carbonate dissolution budgets for shallow-water carbonate sediments have generally not been closed with respect to the observed amount of dissolution and the required amount of acid production from either sediment organic matter remineralization, i.e., aqueous $\mathrm{CO}_{2}$ production, or oxidation of reduced iron and sulfur species, i.e., $\mathrm{H}^{+}$production (Walter and Burton 1990; Walter et al. 1993). Ku et al. (1999) proposed that enhanced oxygen transport into these sediments through the roots and rhizomes of sea grasses (sea grass "pumping") might resolve this mass balance problem. In support of this suggestion, our past work (Burdige and Zimmerman 2002) showed that the belowground input of photosynthetically produced $\mathrm{O}_{2}$ by sea grasses could be an order-of-magnitude larger than $\mathrm{O}_{2}$ inputs via diffusion across the sedimentwater interface.

In addition to providing the oxygen needed to drive sediment carbonate dissolution, sea grass productivity can be an important source of sediment organic matter, the respiration of which produces the acid needed for carbonate dissolution (Hu and Burdige 2007). The overlying leaf canopy also dissipates the energy of local currents and promotes the deposition of organic and inorganic suspended material from the water column to the underlying sediments, particularly in areas dominated by strong tidal currents (see Koch et al. 2006 for a recent summary). 


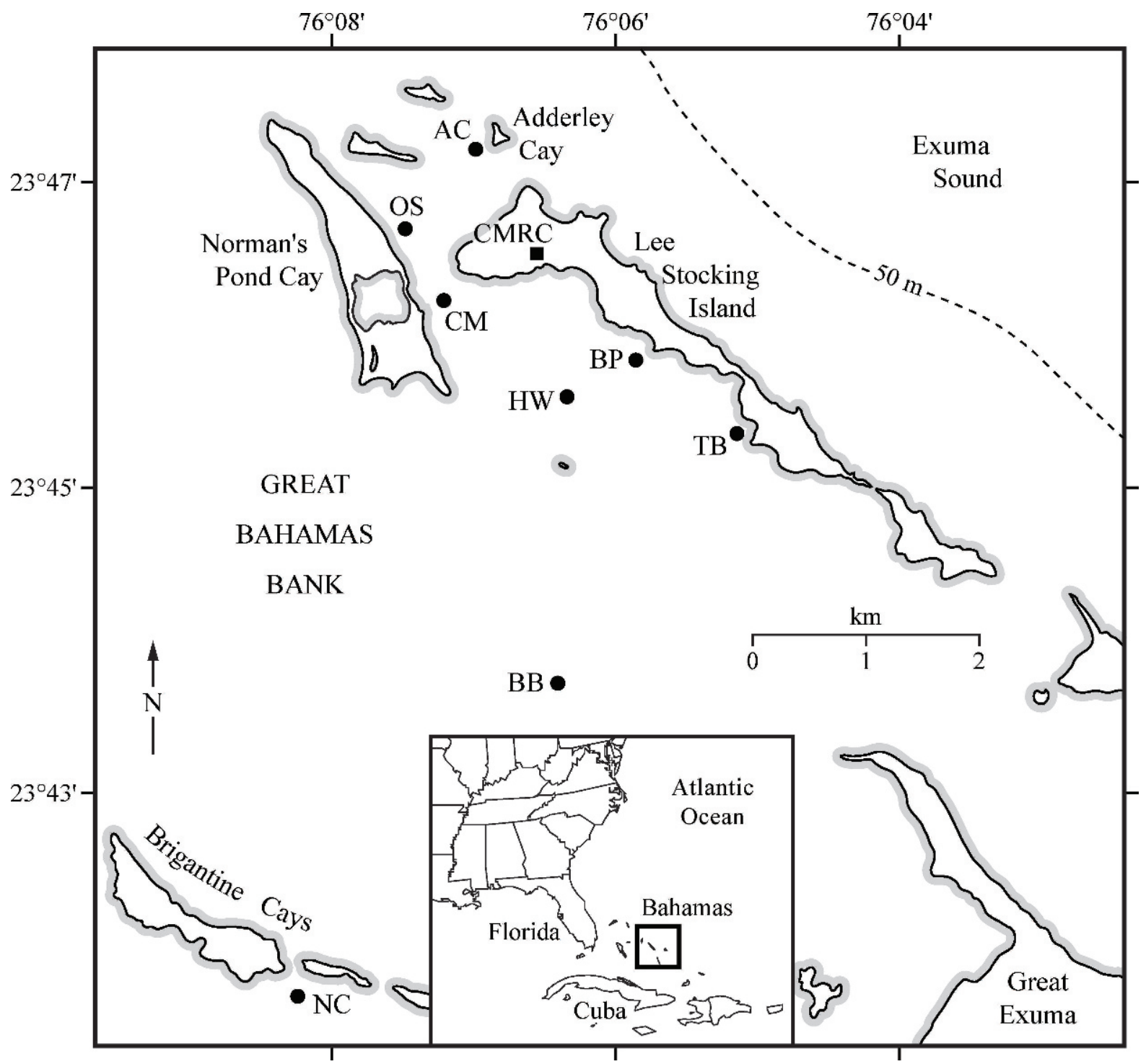

Fig. 1. A map of the field sites near Lee Stocking Island $(\mathrm{CMRC}=$ Caribbean Marine Research Center $)$. Site identification: $\mathrm{AC}=$ Adderley Cut; OS = Ooid Shoals; CM = Channel Marker; HW = Half-Way; BP = Briar Patch; TB = Twin Beaches; BB = Before Brigantines; $\mathrm{NC}=$ New Cay.

These observations demonstrate that strong mechanistic linkages exist between sea grass metabolic processes and sediment diagenesis (in general) and carbonate dissolution (in particular) in shallow-water carbonate sediments. The goal of this study was to more accurately quantify these linkages in sandy sea grass sediments on the Bahamas Bank through the use of an inverse pore-water advection/diffusion/reaction model constrained by field observations. With these results we will also more quantitatively examine the different processes responsible for $\mathrm{O}_{2}$ input to these sediments. A predictive understanding of the relationship between sea grass density and rates of carbonate dissolution will allow for an assessment of the regional and global significance of this process, as remote sensing techniques begin to provide accurate maps of the distribution and abundance of sea grasses in tropical carbonate environments (Dierssen et al. 2003).

\section{Study sites and methods}

Study sites-Studies were conducted in May-June 2002 (referred to hereafter as LSI 6) and 2003 (referred to as LSI 7) near the Caribbean Marine Research Center (CMRC), located on Lee Stocking Island (LSI), Exuma Cays, Bahamas (Fig. 1). Sites around LSI include unvegetated well-sorted oolitic sands and sea grass meadows (mostly Thalassia testudinum or turtle grass) of densities exceeding 500 shoots $\mathrm{m}^{-2}$ (Dill 1991; Burdige and Zimmerman 2002). Water depths at these sites range from $\sim 2-10 \mathrm{~m}$.

The sediments around LSI are fine- to coarse-grained carbonate sands (200-800- $\mu \mathrm{m}$ grain size), composed of skeletal debris, ooids, peloids, and grapestones (Stephens et al. 2003). The dominant mineral phases are aragonite (70$90 \mathrm{wt} \%)$ and high-Mg calcite (10-30 wt \%) with a $\mathrm{Mg}$ 
content of $11-13 \mathrm{~mol} \%$; a small amount of low-Mg calcite (generally $<3 \mathrm{wt} \%)$ is also observed $(\mathrm{Hu}$ and Burdige 2007). Sediment porosities $(\varphi)$ range from $\sim 50 \%$ to $80 \%$ (Burdige and Zimmerman 2002; Wheatcroft 2002).

Sample collection, preparation and analysis-Pore-water samples were collected in situ during daylight hours by divers using pore-water sippers specifically designed for use in sandy sediments (Burdige and Zimmerman 2002; Hu and Burdige 2007). At least three replicate sets of pore-water depth profiles were collected at each site.

After collection, pore-water samples were kept cool in the dark in an ice chest and returned to the lab at CMRC for processing within $1-2 \mathrm{~h}$ of collection. The samples were first equilibrated at room temperature for $30 \mathrm{~min}$, and $\mathrm{O}_{2}$ analyses were then carried out. Unfiltered pore water was taken directly from each sealed glass sipper syringe and introduced into a $\mathrm{N}_{2}$-flushed $1.8-\mathrm{mL}$ serum vial containing a mini stir bar. The vial was sealed with an open-faced cap and Teflon-lined silicone septum, which was then pierced with optical $\mathrm{O}_{2}$ sensor (FOXY-18G, Ocean Optics) connected to a SF2000 spectrophotometer (Ocean Optics). The $\mathrm{O}_{2}$ concentration was recorded after 1 min of constant stirring. The oxygen sensor was calibrated at 30-min intervals using $\mathrm{N}_{2}$ and air-saturated surface seawater following standard linear (Stern-Volmer) calibration $(\mathrm{Hu}$ 2007). The uncertainty of the $\mathrm{O}_{2}$ analyses was $\pm 3 \%$.

After $\mathrm{O}_{2}$ analysis, the remaining pore water was filtered through a $0.45-\mu \mathrm{m}$-diameter nylon disc filter into appropriate storage vessels for subsequent analyses. This included the analysis of total alkalinity $\left(A_{\mathrm{T}}\right)$ by automated Gran titration, dissolved inorganic carbon (DIC or $\sum \mathrm{CO}_{2}$ ) by coulometry, sulfate by ion chromatography, and $\mathrm{pH}$ by electrodes calibrated with National Institute of Standards and Technology-traceable buffers (see Burdige and Zimmerman 2002 or $\mathrm{Hu}$ and Burdige 2007 for additional details about these analytical procedures). The uncertainty of these analyses were $\pm 2 \%\left(A_{\mathrm{T}}\right), \pm 2 \%$ (DIC), and $\pm 4 \%$ (sulfate). "Scripps Reference Seawater for $\mathrm{CO}_{2}$ Measurement" was also used as an external standard for $A_{\mathrm{T}}$ and DIC analyses (Dickson et al. 2003). Dissolved $\mathrm{Ca}^{2+}$ was determined by an automated ethylene glycol-bis( $\beta$-aminoethyl ether) $N, N, N^{\prime}, N^{\prime}$-tetraacetic acid titration with endpoint detection using a $\mathrm{Ca}$ ion-selective electrode, with an uncertainty of $\pm 0.5 \%$ (Kanamori and Ikegami 1980; $\mathrm{Hu}$ 2007). The $\delta^{13} \mathrm{C}$ of the pore-water DIC was also determined on most of these samples; these results are described elsewhere (Hu and Burdige 2007).

Sea grass studies were carried out at each site in parallel with geochemical studies and included the analysis of shoot density (shoots $\mathrm{m}^{-2}$ seafloor) and shoot-specific one-sided leaf area $\left(\mathrm{m}^{2}\right.$ leaf shoot $\left.^{-1}\right)$ in 20 to 40 randomly located $0.1 \mathrm{~m}^{2}$ quadrats at each site. These procedures are described in detail elsewhere (Burdige and Zimmerman 2002; Bodensteiner 2006). Leaf area index (LAI) was calculated as the product of mean shoot density and mean shootspecific, one-sided leaf area, and is therefore defined as square meters of one-sided leaf area per square meter of seafloor $\left(\mathrm{m}^{2}\right.$ leaf $\mathrm{m}^{-2}$ seafloor. $)$ LAI is used as our standard measure of sea grass density.
Results used to model sediment carbonate dissolution rates

Pore-water data-At sites around LSI, pore-water $A_{\mathrm{T}}$, DIC, and $\mathrm{Ca}^{2+}$ concentrations all increased below $\sim 2-4-\mathrm{cm}$ sediment depth (Figs. 2, 3 and Table 1); pore-water $\mathrm{pH}$ and $\mathrm{O}_{2}$ decreased sharply with depth in this same region of the sediments. Sulfate concentrations (expressed here as $\Delta$ sulfate) showed no significant changes with depth.

Bottom waters around LSI are all supersaturated with respect to all carbonate mineral phases found in these sediments (Hu and Burdige 2007). Nevertheless, calculated carbonate ion concentration decreases with depth in the sediments, and saturation state calculations show that pore waters below $\sim 4 \mathrm{~cm}$ are at or near saturation with respect to aragonite (see $\mathrm{Hu}$ and Burdige 2007 for details). All of these observations, and similar results in Burdige and Zimmerman (2002), suggest that carbonate dissolution occurs in LSI sediments and is coupled to $\mathrm{CO}_{2}$ production during aerobic respiration according to

$\mathrm{CaCO}_{3}+\mathrm{CH}_{2} \mathrm{O}+\mathrm{O}_{2}+\mathrm{H}_{2} \mathrm{O} \rightarrow \mathrm{Ca}^{2+}+2 \mathrm{HCO}_{3}^{-}$

This process is often referred to as metabolic carbonate dissolution (e.g., Emerson and Bender 1981). Consistent with the stoichiometry of this reaction, plots of pore-water $A_{\mathrm{T}}$ versus DIC for LSI sediments were linear, with slopes of $\sim 1$ (Burdige and Zimmerman 2002; Hu and Burdige 2007).

A similar linear covariance of $A_{\mathrm{T}}$ and DIC will also be seen if net sulfate reduction occurs in the absence of carbonate dissolution. However, several lines of evidence argue against this latter explanation, including the absence of significant pore-water sulfate depletion with sediment depth (Figs. 2, 3) and the lack of sulfide accumulation with depth in these sediments (Hu and Burdige 2007). The increase in pore-water $\mathrm{Ca}^{2+}$ with sediment depth that tracks the increases in porewater $A_{\mathrm{T}}$ and DIC further argues here for the occurrence of carbonate dissolution, rather than sulfate reduction, in causing the buildup of these pore-water solutes (again see Fig. 2 as well as additional results and discussions of this problem in Burdige and Zimmerman 2002). In examining the processes controlling $A_{\mathrm{T}}$ and DIC production in these sediments we neglect suboxic remineralization processes such as denitrification and metal oxide ( $\mathrm{Mn}$ and $\mathrm{Fe}$ ) reduction because of the low levels of nitrate and $\mathrm{Mn}$ and $\mathrm{Fe}$ oxides in carbonate sediments such as these and the overlying oligotrophic waters (e.g., Morse et al. 1985).

Although there is some evidence for carbonate dissolution in all sediments we have studied (even in the absence of sea grasses), the presence of sea grasses appears to enhance this process. This is seen, for example, in the greater accumulation of carbonate dissolution end product such as DIC in sediments underlying a dense sea grass bed (the CM site) versus that observed in a bare oolitic sand (the OS site; Fig. 3). Additional evidence of this is also seen in Fig. 4, where a strong positive correlation is observed between DIC accumulation in the pore waters and sea grass density (i.e., LAI). Similar trends were seen for other carbonate dissolution end products, namely pore-water alkalinity and $\mathrm{Ca}^{2+}$ (results not shown here). 

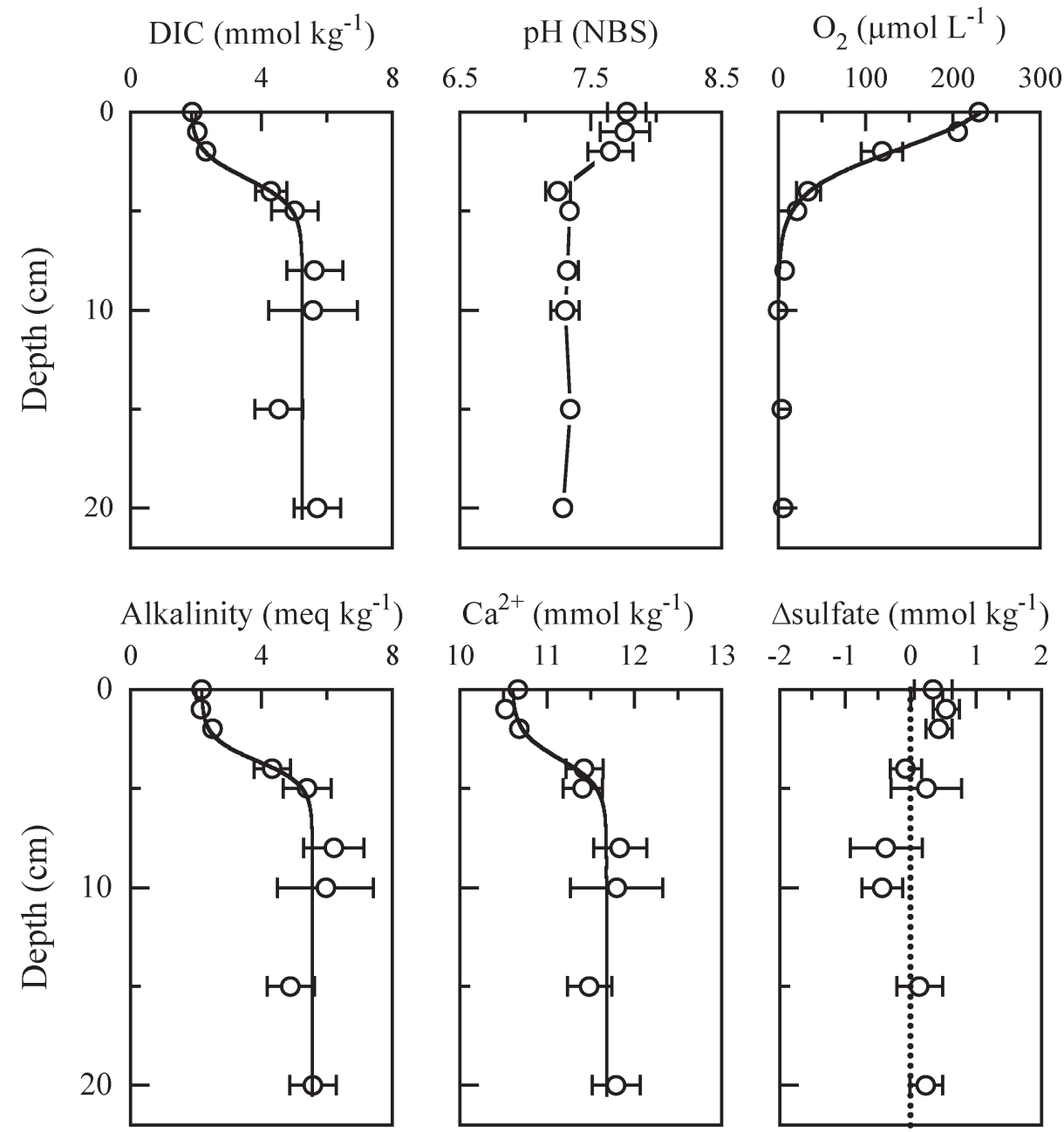

Fig. 2. Typical pore water depth profiles from the CM site (LSI 6). The error bars shown here are standard errors on the basis of replicate $(n \geq 3)$ sets of sipper profiles collected at the site, and the curves through the DIC, alkalinity, $\mathrm{Ca}^{2+}$, and $\mathrm{O}_{2}$ data are the best-fit sigmoid curves based on Eq. 14. $\Delta$ sulfate is the difference between the measured pore-water sulfate concentration and the bottom-water sulfate concentration corrected for any pore-water salinity variation with depth (see Burdige and Zimmerman 2002 and $\mathrm{Hu}$ and Burdige 2007 for details). This approach allows us to differentiate between small changes in pore-water sulfate concentration due to net in situ bacterial sulfate reduction and those that are due to pore-water salinity variations. Note, however, that salinity variations over the upper $20 \mathrm{~cm}$ of sediment at each site were very small (less than $\sim 0.3-0.4$ ) as compared with the individual average salinities in the pore waters at the sites $(\sim 37-38)$.

The results in Fig. 3 indicate that the presence of sea grasses also enhances sediment $\mathrm{O}_{2}$ utilization. For sediments underlying sea grass beds with LAI values less than $\sim 0.8$, sediment oxygen penetration exceeds $20 \mathrm{~cm}$ (the maximum depth of pore-water sampling), whereas for sea grass beds with LAI values greater than $\sim 1$, maximum oxygen penetration in the underlying sediments is generally as shallow as $\sim 3-5 \mathrm{~cm}$. At first glance, this observation appears to be somewhat counterintuitive, given the fact that sea grasses represent a belowground source of $\mathrm{O}_{2}$ to the sediments. However, as was noted in the beginning of this article, sea grasses also enhance the deposition of detrital organic matter from the water column to the sediments and serve as a source of reactive organic matter themselves to the sediments. Sea grasses therefore control sediment aerobic respiration in all of these ways. Furthermore, despite oxygen input to sediments by sea grasses, the enhanced input of sediment organic matter fuels relatively high rates of sediment respiration. This then produces strong oxygen gradients in the upper $\sim 5 \mathrm{~cm}$ of sediments and leads to shallower oxygen penetration depths. Although sediment respiration in bare sands appears to be organic matter limited (e.g., at the OS site), the presence of sea grasses ultimately leads to sediment respiration being $\mathrm{O}_{2}$ limited (e.g., at the $\mathrm{CM}$ or $\mathrm{AC}$ sites).

Belowground oxygen input by sea grasses - Quantifying carbonate dissolution in sea grass sediments requires an 


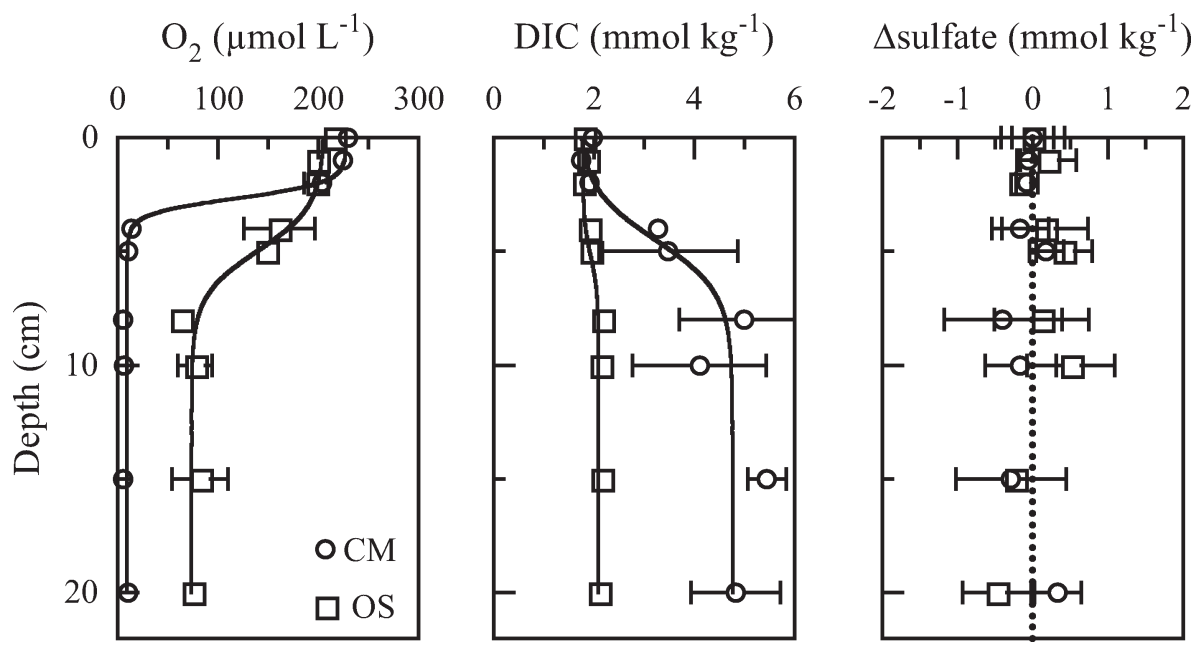

Fig. 3. Comparative oxygen, DIC, and $\Delta$ sulfate pore-water profiles collected during LSI 7 at a dense sea grass site $(\mathrm{CM}$ site; LAI $=1.4)$ and in a bare oolitic sand (OS site; LAI $=0)$. The values shown here are average values on the basis of triplicate sets of sipper profiles collected at each site; error bars are standard errors. The curves through the $\mathrm{O}_{2}$ and DIC data are best-fit sigmoid curves based on Eq. 14.

accurate estimate of belowground oxygen input by the sea grasses. Recent studies measuring root and rhizome tissue metabolic rates and belowground $\mathrm{O}_{2}$ transport by intact plants have shown that turtlegrass transports $6 \%$ of its photosynthetically produced $\mathrm{O}_{2}$ belowground (Bodensteiner 2006). This $\mathrm{O}_{2}$ flux is light dependent, and shows an exponential response similar to that seen for photosynthesis versus irradiance. At the same time, though, roughly $60 \%$ of this belowground $\mathrm{O}_{2}$ transport is consumed by respiration within the roots and rhizomes, with $40 \%$ then directly released into the sediments as a direct sea grasssediment $\mathrm{O}_{2}$ flux.

Using the same experimental procedures, Bodensteiner (2006) also demonstrated with Zostera marina (eelgrass) that $\sim 4 \%$ of the photosynthetically produced $\mathrm{O}_{2}$ is transported below ground, although in eelgrass a higher percentage $(\sim 87 \%)$ of this oxygen is consumed by root and rhizome respiration. This then results in a net belowground sea grass-sediment $\mathrm{O}_{2}$ flux by eelgrass that equals $\sim 1 \%$ of total photosynthetic $\mathrm{O}_{2}$ production, in excellent agreement with analogous split chamber (Sand-Jensen et al. 1982) as well as planar optode (Frederiksen and Glud 2006) studies with eelgrass. This agreement between Bodenstenier's (2006) results for eelgrass and these other eelgrass studies provides us with confidence in using her results for turtlegrass in modeling biogeochemical processes such as carbonate dissolution in LSI sediments.

The results of Bodensteiner (2006) imply that the belowground transport of $\mathrm{O}_{2}$ by turtlegrass equals $1.2 \mathrm{mmol} \mathrm{m} \mathrm{m}^{-2}$ leaf $\mathrm{h}^{-1}$, assuming photosynthesis is light saturated, or $10.8 \mathrm{mmol} \mathrm{m}^{-2}$ leaf $\mathrm{d}^{-1}$, if the plants produce $\mathrm{O}_{2}$ for $9 \mathrm{~h}$ per day. For a given site, multiplying this daily "per plant" (i.e., per $\mathrm{m}^{2}$ leaf area) belowground oxygen input by LAI allows us to estimate the total daily integrated amount of $\mathrm{O}_{2}$ transported below ground by turtlegrass per square meter of seafloor.

Table 1. One-way analysis of variance for the significance of the depth profiles presented in Fig. 2. df $=$ degrees of freedom; MS = mean square; $F=F$ statistic; $p=$ probability of a constant parameter value with depth, significance: $*=<0.05, * *=<0.01, * * *=$ $<0.001 ; b_{\text {crit }}=$ critical boundary between bottom water and pore water, on the basis of least significant differences (post hoc multiple comparisons) among samples taken at all depths; n.s., not significant.

\begin{tabular}{|c|c|c|c|c|c|c|}
\hline Pore water solute & $\mathrm{df}$ & MS & $F$ & $p$ & Significance & $b_{\text {crit }}(\mathrm{cm})$ \\
\hline DIC & 8 & 20.23 & 7.91 & $<0.001$ & $* * *$ & 4 \\
\hline Error & 62 & 2.56 & & & & \\
\hline $\mathrm{pH}$ & 8 & 0.409 & 2.81 & $<0.01$ & $* *$ & 4 \\
\hline Error & 66 & 0.146 & & & & \\
\hline $\mathrm{O}_{2}$ & 8 & 70,547 & 59.67 & $<0.001$ & $* * *$ & 5 \\
\hline Error & 66 & 1182 & & & & \\
\hline Alkalinity & 8 & 21.9 & 7.90 & $<0.01$ & $* *$ & 4 \\
\hline Error & 66 & 2.8 & & & & \\
\hline $\mathrm{Ca}^{2+}$ & 8 & 2.14 & 6.17 & $<0.001$ & $* * *$ & 4 \\
\hline Error & 58 & 0.35 & & & & \\
\hline$\Delta$ Sulfate & 8 & 0.53 & 0.57 & 0.80 & n.s. & n.s. \\
\hline Error & 58 & 0.93 & & & & \\
\hline
\end{tabular}




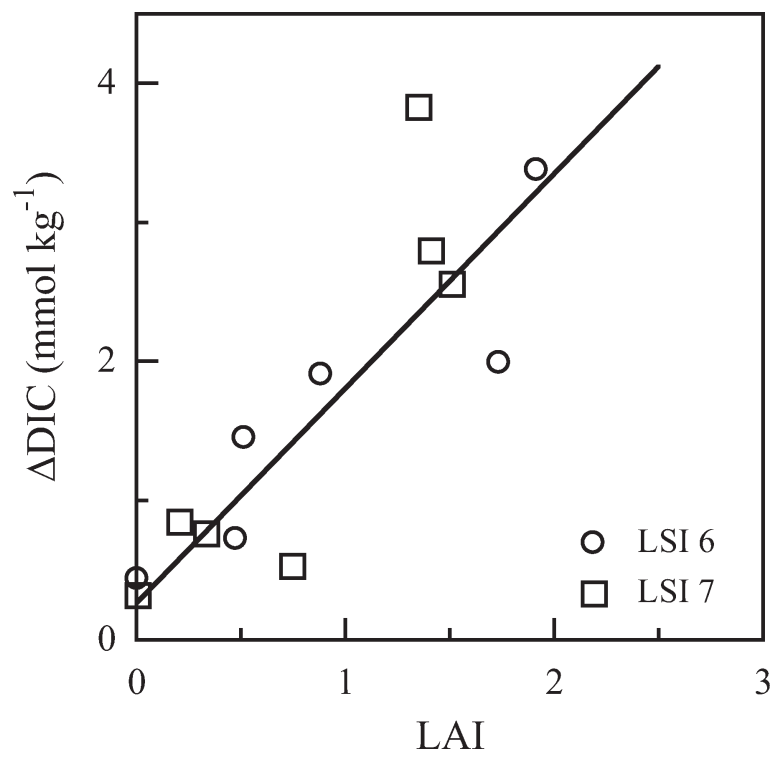

Fig. 4. $\triangle \mathrm{DIC}$ versus LAI for all sites around LSI. $\triangle \mathrm{DIC}$ is defined here as the difference between the average pore-water concentration between 10 and $20 \mathrm{~cm}$ and the bottom-water value. The best-fit straight line through the data is meant to illustrate the trends in the data and is not meant to imply any known functional relationship. However, the $r^{2}$ value for this line is $0.74(p<0.001)$, indicating that there is a high degree of correlation between these two quantities.

In our advection/diffusion/reaction model described below, this belowground sea grass $\mathrm{O}_{2}$ flux was distributed through the sediment column on the basis of the relative vertical distribution of sea grass root and rhizome biomass (Fig. 5). In contrast, we note that the sea grasses Z. marina and Halophilia ovalis have both been shown to release $\mathrm{O}_{2}$ into the sediments primarily from the tips of actively growing roots, with little radial loss of oxygen from most of the length of the roots and rhizomes (Connell et al. 1999; Jensen et al. 2005; Frederiksen and Glud 2006). Although the root tips of $T$. testudinum may also show similar enhanced $\mathrm{O}_{2}$ release, the roots of turtlegrass plants growing near LSI are short and less abundant than in other sea grass species. Furthermore, they rarely extend much below the depth of the main (horizontal) rhizome $(\sim 5-10 \mathrm{~cm})$. This then makes the root distribution relatively consistent with the overall distribution of belowground biomass. As a result, we therefore feel that the approach we have taken here is not an unreasonable first approach to estimate the depth distribution of belowground turtlegrass $\mathrm{O}_{2}$ input.

Evidence for pore-water advection in LSI sediments-The pore-water data presented here are broadly consistent with metabolic carbonate dissolution mediated by sea grass $\mathrm{O}_{2}$ input into the sediments. However, these pore-water profiles also show relatively small concentration changes in the upper $\sim 2-4 \mathrm{~cm}$ (relative to bottom water values), with pore-water concentrations then changing rapidly below this surface zone of the sediments (see Table 1 and Figs. 2, 3). Such profiles likely result from pore-water advection through the upper sediments (see similar discussions in Burdige and Zimmerman 2002).

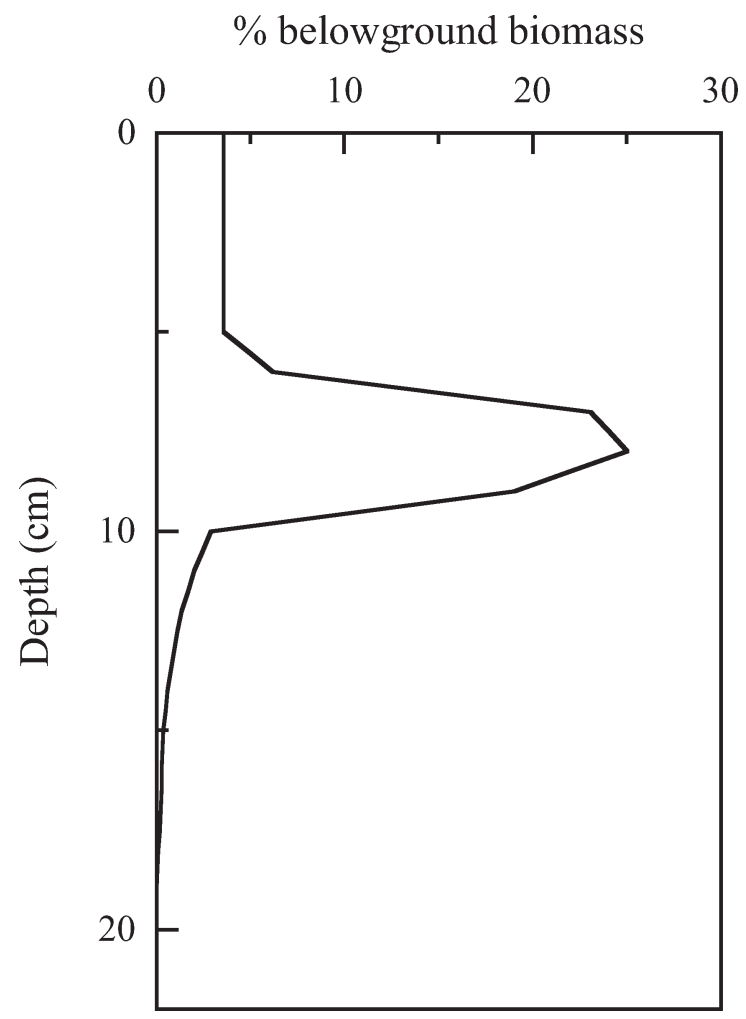

Fig. 5. The depth distribution of belowground biomass for Thalassia testudinum (adapted from Bodensteiner 2006). The depth distribution of belowground sea grass oxygen input was determined using this biomass distribution as described in the text.

This advective flow is governed by Darcy's law (e.g., Lerman 1979; Boudreau 1997; Huettel and Webster 2001), with the relevant quantities controlling the magnitude of this advection being the sediment permeability factor $k$ as well as the near-seabed pressure gradient field. On local scales these pressure gradients are likely three-dimensional (3D), and can result in complex 3D advective flow fields (e.g., Huettel et al. 1996). These pressure gradients can be generated by wave action (oscillating bottom currents), or by bottom water flow over surface topography (e.g., sand ripples or physical surface roughness), biogenic structures such as animal mounds, or submerged sea grass canopies (Boudreau et al. 2001; Huettel and Webster 2001; Koch et al. 2006). A variety of factors controls the magnitude and directionality of these pressure gradients, including the size and distribution of these biogenic structures, as well as bottom current speeds. In flume studies with unidirectional flow over sandy sediments containing biogenic or synthetic sediment mounds, current speed has been shown to increase the interfacial pressure gradient $(\partial p / \partial z$ where $z$ is sediment depth positive downward), and hence pore-water advective flow (Huettel et al. 1996) as well as the sediment oxygen penetration depth (Ziebis et al. 1996).

Numerous studies of pore-water advective transport in permeable sediments have focused on seabed pressure gradients caused by surface "microtopography" (e.g., animal sediment mounds), as opposed to effects associated with more large-scale features such as dense sea grass 
meadows (see Boudreau and Jøregensen 2001 for a summary). The effects of sea grass canopies on bottom water flow and near-seabed pressure gradients are complex and not fully understood, although past studies suggest that the most important variables include canopy architecture (shoot density, leaf length) as well as the type of flow (e.g., unidirectional tidal currents vs. wave-dominated flow) and its effect on the motion of individual leaves (see Koch et al. 2006 for a recent review).

Another important factor controlling this type of advective transport is the permeability of the sediment, expressed by the permeability factor $k$. Permeability depends on the sediment texture, or fabric, and is a complex function of sediment particle size, porosity, and particle packing (see general discussions in Friedman and Sanders 1978; Lerman 1979). In sediments where the permeability exceeds $\sim 10^{-12} \mathrm{~m}^{2}$ advective transport is thought to be significant down to sediment depths of at least several centimeters (Huettel and Webster 2001). The calculated permeability of LSI sediments is greater than $\sim 10^{-10} \mathrm{~m}^{2}$ (Burdige and Zimmerman 2002), and Bennett et al. (1990) report comparable measured in situ permeabilities in other similar carbonate sediments on the Bahamas Bank. These observations provide additional evidence that advection plays a significant role in structuring pore-water profiles in LSI sediments.

Finally, as evidence for the occurrence of pore-water advection in LSI sediments, we have observed that depthintegrated rates of turtlegrass $\mathrm{O}_{2}$ input to these sediments (estimated as discussed in the previous section) predict depth-integrated rates of $A_{\mathrm{T}}$, DIC, and $\mathrm{Ca}^{2+}$ production on the basis of Eq. 1 that are up to several orders of magnitude greater than their diffusive fluxes out of the sediments. These diffusive fluxes were calculated with gradients at the sediment-water interface $\left(\mathrm{d} C / \mathrm{d} z_{\mathrm{o}}\right)$ determined in two ways: linear gradients calculated as the difference between the concentration in the first sediment pore-water sample and in the bottom water, divided by the depth of the pore-water sample (e.g., Burdige et al. 1999); gradients estimated with the first derivative of the sigmoid function fit to each complete pore water profile (see Eq. 14 and accompanying discussions, as well as Figs. 2, 3). Under steady-state conditions the total benthic flux of a solute out of the sediments equals its depth-integrated rate of production (Burdige 2006). As a result, these imbalances require an additional mechanism other than diffusion (i.e., advection) to transport carbon oxidation and carbonate dissolution end products out of LSI sediments.

These advective processes not only remove alkalinity, DIC, or $\mathrm{Ca}^{2+}$ from the sediments, but they also transport dissolved oxygen into sediments. However, to a first approximation the $\mathrm{O}_{2}$ concentration differences between bottom waters and porewaters are roughly an order-ofmagnitude smaller than similar differences for these carbon oxidation and carbonate dissolution end products (e.g., see Figs. 2, 3). Therefore this leads to the apparent "preferential" advective transport of these oxidation and dissolution end products out of the sediments relative to the advective input of oxygen. Qualitatively, this then suggests that advective transport of carbon oxidation and dissolution end products out of the sediments may aid in countering the input of $\mathrm{O}_{2}$ to the sediments by sea grasses. This point will be explored more quantitatively in the model described below.

\section{Description of the pore-water model}

Modeling advective transport processes in permeable sediments - In muddy, low-permeability sediments, transport processes such as diffusion, bioturbation, and bioirrigation are relatively well parameterized in models of sediment diagenesis (see Boudreau 1997 and Burdige 2006 for summaries). In contrast, solute transport processes in sandy, high-permeability sediments are more complex and not nearly as well represented mathematically (Boudreau et al. 2001; Webster 2003). For these reasons, modeling of pore-water profiles in high-permeability sediments is much more difficult.

Past studies have used two different empirical approaches to model nondiffusive solute transport in highpermeability sediments. The first approach assumes that there is a region near the sediment-water interface (typically the upper $\sim 5-10 \mathrm{~cm}$ of sediment) in which enhanced pore-water transport is treated as a diffusive-like process (sometimes referred to as dispersion), with an apparent diffusion coefficient $\left(D_{\mathrm{E}}\right)$ that is greater than the molecular diffusion coefficient $\left(D_{\mathrm{M}}\right)$. In this formalism, $D_{\mathrm{E}}$ may be taken to be a constant in this surface zone (Lohse et al. 1996), or to decrease exponentially from $D_{\mathrm{E}}$ to $D_{\mathrm{M}}$ over the depth of this surface zone (Jahnke et al. 2005).

An alternate approach to this problem assumes that pore-water advective transport can be modeled as nonlocal advective exchange between bottom waters and pore waters at some sediment depth (e.g., Boudreau 1997). Mathematically, this type of exchange is expressed as

$$
V(z)=\alpha_{z}\left(C_{z}-C_{o}\right)
$$

where $C_{\mathrm{z}}$ is the pore-water concentration at depth $z, C_{\mathrm{o}}$ is the bottom-water concentration, and $\alpha_{\mathrm{z}}$ is the nonlocal exchange coefficient. Again, this coefficient may be assumed to be a constant or to decrease exponentially with depth in the region of the sediments where this exchange occurs (Marinelli et al. 1998; Jahnke et al. 2005).

Recently, both approaches to quantifying pore-water advective transport were used to model pore-water profiles from sandy, continental margin sediments (Jahnke et al. 2005). Whereas both provide reasonable fits to the porewater data, neither is well grounded theoretically and it is therefore difficult at the present time to critically ascertain which approach is more appropriate. In this study, we have chosen to use the nonlocal exchange model to characterize advective pore-water transport in LSI sediments, and to parameterize the depth dependence of $\alpha_{z}$ using an exponential function,

$$
\alpha_{z}=\alpha_{o} e^{-\beta z}
$$

This latter approach is also consistent with observations that suggest that the type of pore-water advection being considered here attenuates with depth in an exponentiallike fashion (e.g., Huettel et al. 1996; Reimers et al. 2004). 
An additional advantage of parameterizing pore-water advection using Eqs. 2 and 3 is that it will also incorporate any pore-water transport associated with bioirrigation by benthic macrofauna (e.g., Boudreau 1997). On the basis of visual observations of LSI sediments, we believe that this process is likely to be of secondary importance at all sites except at the TB site, where the bottom topography contains extensive conical mounds built by the burrowing shrimp Callianasa (e.g., see Ziebis et al. 1996, for photographs of analogous sediments in the Mediterranean Sea).

An advection-diffusion reaction (ADR) model for permeable sea grass sediments - To model pore-water data from LSI sediments, we start by considering the following ADR equation for dissolved oxygen,

$$
0=D_{s} \frac{\partial^{2} C}{\partial z^{2}}+\gamma P(z)-V(z)-R(z)
$$

where $D_{s}$ is the molecular diffusion coefficient corrected for tortuosity (Burdige and Zimmerman 2002), $V(z)$ is porewater advection through these high-permeability sediments (see Eqs. 2 and 3), and $R(z)$ is sediment $\mathrm{O}_{2}$ consumption, or respiration. The term $\gamma P(z)$ is the depth-dependent input of $\mathrm{O}_{2}$ by sea grasses directly into the sediments, where the belowground transport of photosynthetically produced $\mathrm{O}_{2}$ by sea grasses has been corrected for root and rhizome respiration $\left(\mathrm{O}_{2}\right.$ consumption). The results in Bodensteiner (2006) indicate that $\gamma=0.4$ (see the section "Belowground oxygen input by sea grasses" for details); $P(z)$ was also parameterized as described in this section.

A similar ADR equation can be written for alkalinity in the pore waters,

$$
0=D_{s} \frac{\partial^{2} C}{\partial z^{2}}-V(z)+R(z)
$$

where here $R(z)$ is the sediment alkalinity production rate, and we now omit the term $P(z)$, since sea grasses do not directly add alkalinity to the pore waters. For DIC, we assume that $\mathrm{CO}_{2}$ produced in the roots and rhizomes by downwardly transported $\mathrm{O}_{2}$ is released into the sediments along with the residual $\mathrm{O}_{2}$ (see discussion in Bodensteiner 2006), and that there is a $1: 1$ relationship between $\mathrm{O}_{2}$ consumption and DIC production in the roots and rhizomes (e.g., see Eq. 1). The ADR equation for DIC is therefore,

$$
0=D_{s} \frac{\partial^{2} C}{\partial z^{2}}-V(z)+R(z)+(1-\gamma) P(z)
$$

where here $R(z)$ and $(1-\gamma) P(z)$ represent DIC production rates due to metabolic carbonate dissolution from two $\mathrm{CO}_{2}$ sources - respiration in the sediments and respiration in the roots and rhizomes (see the next section for details).

The ADR equations for these solutes are written in steady-state form, despite the fact that $P(z)$ is clearly a timedependent process (i.e., $\mathrm{O}_{2}$ production by photosynthesis occurs only during daylight hours). Carbonate dissolution rates may similarly show diurnal variability (e.g., Yates and Halley 2006). However, we implicitly assume that the porewater profiles we have determined are quasi-steady-state profiles over the diurnal cycle; we have also incorporated the temporal variability of $P(z)$ as discussed previously. The term $V(z)$ in all equations is also likely time dependent since tidal currents around LSI largely create the pressure gradients that drive this advective flow. Thus, values of $V(z)$ represent values that are averaged over the tidal cycle.

An inverse solution of the pore water model for sea grassdominated, permeable sediments - In working with these equations we have chosen to take an inverse modeling approach to estimate $R(z)$ for each pore water solute (see additional discussions of this modeling approach in Burdige 2006). To do this, we first rewrite Eqs. 4-6 in terms of $R(z)$, explicitly rewrite $V(z)$ on the basis of Eqs. 2 and 3 , and also define $O x, A c$, and $D c$ as the pore-water concentrations of dissolved oxygen, alkalinity, and DIC,

$$
\begin{gathered}
R_{O}(z)=D_{s} \frac{\partial^{2} O x}{\partial z^{2}}+\gamma P(z)-\left[\left(\alpha_{o} e^{-\beta z}\right)\left(O x-O x_{o}\right)\right] \\
R_{A}(z)=-D_{s} \frac{\partial^{2} A c}{\partial z^{2}}+\left[\left(\alpha_{o} e^{-\beta z}\right)\left(A c-A c_{o}\right)\right] \\
R_{D}(z)=-D_{s} \frac{\partial^{2} D c}{\partial z^{2}}-(1-\gamma) P(z) \\
+\left[\left(\alpha_{o} e^{-\beta z}\right)\left(D c-D c_{o}\right)\right]
\end{gathered}
$$

In this model, we are ultimately interested in quantifying the belowground $\mathrm{CO}_{2}$ production that drives carbonate dissolution, and an examination of the discussion above indicates that there are two possible sources of this acidmicrobial respiration in the sediments and respiration in belowground root and rhizome tissues. By rewriting Eq. 9 we obtain

$$
\begin{aligned}
R_{D}(z)+(1-\gamma) P(z)= & -D_{s} \frac{\partial^{2} D c}{\partial z^{2}} \\
& +\left[\left(\alpha_{o} e^{-\beta z}\right)\left(D c-D c_{o}\right)\right]
\end{aligned}
$$

or

$$
R_{D}^{T}(z)=-D_{s} \frac{\partial^{2} D c}{\partial z^{2}}+\left[\left(\alpha_{o} e^{-\beta z}\right)\left(D c-D c_{o}\right)\right]
$$

where the two terms on the left side of Eq. 10 are combined and referred to as $R_{D}^{T}(z)$. The term $R_{D}^{T}(z)$ now incorporates these two belowground $\mathrm{CO}_{2}$ production processes (that contribute to carbonate dissolution), plus DIC production from the dissolving sediment carbonate. In a similar fashion, by adding the term $(1-\gamma) P(z)$ to both sides of Eq. 7, this equation becomes

$$
\begin{aligned}
R_{O}(z)+(1-\gamma) P(z)= & D_{s} \frac{\partial^{2} O x}{\partial z^{2}}+P(z) \\
& -\left[\left(\alpha_{o} e^{-\beta z}\right)\left(O x-O x_{o}\right)\right]
\end{aligned}
$$

or

$R_{O}^{T}(z)=D_{s} \frac{\partial^{2} O x}{\partial z^{2}}+P(z)-\left[\left(\alpha_{o} e^{-\beta z}\right)\left(O x-O x_{o}\right)\right]$ 
Table 2. Best-fit parameters $\left(G, B, F\right.$, and $d$; see Eq. 14) and fitting statistics $\left(r^{2}\right.$ and $\left.p\right)$ for the LSI pore-water $\mathrm{O}_{2}$, DIC, and alkalinity profiles ( $p$ is the significance of the fit to the data [i.e., the probability that the $r^{2}$ value occurred by chance], and is based on the $F$ statistic for the fit).

\begin{tabular}{|c|c|c|c|c|c|c|}
\hline LSI 6 & $\mathrm{CM}$ & $\mathrm{AC}$ & HW & TB & OS & BP \\
\hline \multicolumn{7}{|c|}{ Oxygen } \\
\hline$G$ & 0 & 0 & 6.9 & 16.6 & 73.8 & 40.7 \\
\hline$B$ & 274 & 206 & 184 & 308 & 135 & 176 \\
\hline$F$ & 0.2 & 0.0002 & 0.01 & 0.5 & 0.06 & 0.06 \\
\hline$D$ & 0.9 & 2.44 & 1.7 & 0.5 & 0.99 & 1.54 \\
\hline$r^{2}$ & 0.83 & 0.99 & 0.95 & 0.92 & 0.84 & 0.81 \\
\hline$p$ & $<0.001$ & $<0.001$ & $<0.001$ & $<0.001$ & $<0.001$ & 0.01 \\
\hline \multicolumn{7}{|l|}{ DIC } \\
\hline$G$ & 1.8 & 1.8 & 1.9 & 3.0 & 1.7 & 1.8 \\
\hline$B$ & 3.4 & 1.8 & 1.4 & -72.1 & 0.5 & 2.0 \\
\hline$F$ & 112.7 & 1,000 & 26.9 & 55.0 & 21.3 & 14.9 \\
\hline$d$ & -1.4 & -2.3 & -1.0 & 0.1 & -1.2 & -0.5 \\
\hline$r^{2}$ & 0.63 & 0.74 & 0.43 & 0.61 & 0.68 & 0.52 \\
\hline$p$ & $<0.001$ & $<0.001$ & $<0.001$ & $<0.001$ & $<0.001$ & 0.37 \\
\hline \multicolumn{7}{|c|}{ Alkalinity } \\
\hline$G$ & 2.2 & 1.9 & 2.0 & 4.1 & 2.1 & 2.4 \\
\hline$B$ & 3.4 & 1.8 & 1.5 & 7,606 & 0.4 & 1.3 \\
\hline$F$ & 387 & 1,000 & 13 & $-3,250$ & 604 & 5,306 \\
\hline$d$ & -1.7 & -2.2 & -0.8 & 0.03 & -1.7 & -3.2 \\
\hline$r^{2}$ & 0.51 & 0.63 & 0.31 & 0.25 & 0.56 & 0.30 \\
\hline$p$ & $<0.001$ & $<0.001$ & 0.02 & 0.05 & $<0.0001$ & 0.33 \\
\hline LSI 7 & $\mathrm{CM}$ & $\mathrm{AC}$ & HW & OS & $\mathrm{NC}$ & $\mathrm{BB}$ \\
\hline \multicolumn{7}{|c|}{ Oxygen } \\
\hline$G$ & 9.4 & 7.3 & 28.6 & 73.5 & 11.9 & 18.9 \\
\hline$B$ & 218 & 998 & 191 & 132 & 186 & 196 \\
\hline$F$ & 0.0004 & 3.3 & 0.004 & 0.006 & 0.00003 & 0.00002 \\
\hline$D$ & 2.9 & 0.3 & 1.5 & 1.0 & 5.5 & 8.6 \\
\hline$r^{2}$ & 0.99 & 0.66 & 0.97 & 0.77 & 0.97 & 0.92 \\
\hline$p$ & $<0.001$ & $<0.001$ & $<0.001$ & $<0.001$ & $<0.001$ & $<0.001$ \\
\hline \multicolumn{7}{|l|}{ DIC } \\
\hline$G$ & 1.7 & 1.9 & 1.9 & 1.8 & 0 & 0.2 \\
\hline$B$ & 3.1 & 2.7 & 0.6 & 0.3 & 8.3 & 3.6 \\
\hline$F$ & 49.4 & 39.6 & 500 & 709 & 2.9 & 1.1 \\
\hline$D$ & -0.9 & -0.6 & -1.5 & -1.3 & -0.1 & -0.1 \\
\hline$R^{2}$ & 0.57 & 0.68 & 0.39 & 0.63 & 0.64 & 0.41 \\
\hline$p$ & 0.001 & $<0.001$ & 0.04 & $<0.001$ & $<0.001$ & 0.03 \\
\hline \multicolumn{7}{|c|}{ Alkalinity } \\
\hline$G$ & 1.8 & 2.0 & 2.1 & 2.0 & 0 & 1.0 \\
\hline$B$ & 3.5 & 2.7 & 0.4 & 0.2 & 7.1 & 2.8 \\
\hline$F$ & 32.6 & 105.5 & 500 & 500 & 2.3 & 1.8 \\
\hline$D$ & -0.6 & -0.7 & -1.5 & -1.0 & -0.2 & -0.1 \\
\hline$r^{2}$ & 0.61 & 0.69 & 0.22 & 0.62 & 0.53 & 0.44 \\
\hline$p$ & $<0.001$ & $<0.0001$ & 0.30 & $<0.001$ & 0.002 & 0.02 \\
\hline
\end{tabular}

where here $R_{O}^{T}(z)$ similarly represents the sum of $\mathrm{O}_{2}$ consumption in the sediments and in belowground sea grass roots and rhizomes. Since all alkalinity production comes from carbonate dissolution, which occurs outside of the sea grass root and rhizome, there is no need to make analogous modifications to the equation defining alkalinity production (Eq. 8).

Next, we fit pore-water data to a sigmoid function of the form

$$
C=G+\frac{B}{1+F e^{d z}}
$$

since this equation nicely reproduces the general shape of these profiles (e.g., Figs. 2, 3), and also has continuous first and second derivatives. For each solute at a given site (and sampling date) the entire set of data for concentration versus depth were fit to Eq. 14 using a nonlinear curvefitting routine in the program SigmaPlot ${ }^{\circledR}$ on the basis of the Marquardt-Levenberg algorithm (Press et al. 2001). In this procedure, the parameters $G, B, F$, and $d$ in Eq. 14 were used as adjustable fitting parameters. The best-fit parameters and fitting statistics for all profiles are summarized in Table 2. Of the 36 data sets fit to Eq. 14 (three solutes per 
site $\times$ six sites per trip $\times$ two sampling trips), the $r^{2}$ values ranged from 0.99 to 0.20 , with a mean $r^{2}$ of $0.64( \pm 0.04)$. However, the significance of these correlations was quite high, with the majority of these fits (19 of 36) having $p<$ 0.0001 , and $\sim 90 \%$ of these fits (31 of 36) having $p<0.05$.

With these best-fit curves we can mathematically express the depth dependence of the diffusive flux terms and the pore-water advection terms in Eqs. 8, 11, and 13. As a result, the depth distributions of $R_{O}^{T}(z), R_{D}^{T}(z)$, and $R_{A}(z)$ for these three pore-water solutes are now defined by $P(z)$, the best-fit sigmoid curves to individual pore-water profiles and the second derivatives of these best-fit curves; the only unknown parameters are $\alpha_{o}$ and $\beta$ [also note that because of the ways that $R_{O}^{T}(z)$ and $R_{D}^{T}(z)$ are defined in Eqs. 11 and 13 , they are now independent of $\gamma]$. To constrain the values of these two advection parameters we use the depthintegrated rates of belowground consumption $\left(\mathrm{O}_{2}\right)$ or production $\left(A_{\mathrm{T}}\right.$ and DIC) of each solute, defined here as,

$$
\begin{aligned}
& \text { DIRO }=\int R_{O}^{T}(z) \mathrm{d} z \\
& \text { DIRA }=\int R_{A}(z) \mathrm{d} z \\
& \text { DIRD }=\int R_{D}^{T}(z) \mathrm{d} z
\end{aligned}
$$

Each of these depth-integrated rates can now also be considered to be "functions" of $\alpha_{o}$ and $\beta$. Integration of Eqs. 15-17 was done by trapezoidal approximation at 0.5$\mathrm{cm}$ intervals, again down to $20 \mathrm{~cm}$.

If we assume that these nonlocal advection parameters are solute independent, then the "best-fit" values of $\alpha_{o}$ and $\beta$ must predict depth-integrated rates of solute production or consumption that satisfy mass balance constraints that are based on the stoichiometry of Eq. 1, i.e.,

$$
\begin{aligned}
& \text { 2DIRO }=\text { DIRD } \\
& \text { 2DIRO }=\text { DIRA } \\
& \text { DIRD }=\text { DIRA }
\end{aligned}
$$

Defining each of these mass balance constraints as " $X=$ $Y$," then the error of each constraint is

$$
e r r=\left|\frac{X-Y}{0.5(X+Y)}\right|
$$

and the average of these three error estimates is defined as $e r r_{\text {avg. }}$ For each set of profiles the values of $\alpha_{o}$ and $\beta$ that minimize $e r r_{\text {avg }}$ were obtained using the "Solver" routine in Microsoft Excel ${ }^{\circledR}$ (see Tables 3 and 4).

Implicit in the mass balance approach described here is the assumption that Eq. 1 describes the dominant processes affecting $\mathrm{O}_{2}$, alkalinity, and DIC in these sediments. We believe this is justified for two key reasons. First, much of the $\mathrm{O}_{2}$ input to these sediments occurs (by sea grass pumping) several centimeters below the sediment surface
(Fig. 5), implying that $\mathrm{CO}_{2}$ production from the utilization of this $\mathrm{O}_{2}$ occurs relatively far from the sediment-water interface. Similar considerations also apply to direct $\mathrm{CO}_{2}$ input from root and rhizome respiration. As a result, neutralization of both types of $\mathrm{CO}_{2}$ by carbonate ion in the bottom waters (rather than by sediment carbonate dissolution) is minimized (see $\mathrm{Hu}$ and Burdige 2007 for further details). Incubation studies with Bahamas Bank sediments have also shown that rates of carbonate dissolution are fast relative to respiration rates $(\mathrm{Hu}$ 2007), further implying a tight coupling between metabolic $\mathrm{CO}_{2}$ production and carbonate dissolution, again consistent with Eq. 1.

On the basis of the stoichiometry of Eq. 1 the resulting best-fit values of DIRO, DIRA, DIRD can be used to estimate depth-integrated rates of overall sediment organic carbon oxidation $\left(R_{\text {cox }}\right)$ and sediment carbonate dissolution $\left(R_{\mathrm{CD}}\right)$ as follows,

$$
\begin{aligned}
R_{\mathrm{CD}} & =\text { DIRO } \\
& =0.5 \mathrm{DIRA} \\
& =0.5 \mathrm{DIRD} \\
& =\text { DIRD }-0.5 \mathrm{DIRA} \\
R_{\mathrm{cox}} & =\text { DIRO } \\
& =0.5 \mathrm{DIRA} \\
& =0.5 \mathrm{DIRD}
\end{aligned}
$$

(see Burdige and Zimmerman 2002 for further details). These results are also listed in Tables 3 and 4 .

As an internal check on the model results, we determined numerical solutions to Eqs. 4-6 using a centered finitedifferencing scheme (Crank 1975) that incorporates into the solution the "best-fit" values of $\alpha_{o}$ and $\beta$, the resulting $R(z)$ profiles for each solute, and the depth distribution of $P(z)$. Such numerical solutions were compared with the curves based on Eq. 14 that were fit to the original data, and that formed the basis of the solution to the inverse model. In all cases the original best-fit curves and these numerical solutions agreed with one another to within less than $5 \%$, and in many cases they agreed with one another to within less than $1 \%$. The numerical solutions and best-fit curves were also indistinguishable from one another when plotted together (e.g., see Figs. 2, 3).

Finally, we note that we have specifically chosen to not use depth-integrated rates of pore-water $\mathrm{Ca}^{2+}$ production, estimated from pore-water $\mathrm{Ca}^{2+}$ profiles, in the mass balance fitting procedure described here. We have taken this approach since to use this information requires knowledge of the specific carbonate phase undergoing dissolution (e.g., aragonite vs. high- $\mathrm{Mg}$ calcite) and, more importantly, its $\mathrm{Mg}$ (vs. Ca) content. It also requires knowledge about the possible occurrence of carbonate reprecipitation in conjunction with carbonate dissolution, and the composition (i.e., Mg content) of any secondary carbonate that forms by reprecipitation (e.g., see discussions in Rude and Aller 1991; Hover et al. 2001; Hu and Burdige 2007). Addressing these problems are beyond the 
Table 3. Model-derived results obtained with the LSI 6 pore water data (Abbreviations: DIRO = depth-integrated rate of sediment oxygen utilization (Eq. 15); DIRD = depth-integrated rate of sediment DIC production (Eq. 17); DIRA = depth-integrated rate of sediment alkalinity production (Eq. 16); nd $=$ not determined; $R_{\text {cox }}=$ depth-integrated rate of sediment organic matter oxidation (Eq. 23); $R_{\mathrm{CD}}=$ depth-integrated rate of sediment carbonate dissolution (Eq. 22); LAI = leaf area index).

\begin{tabular}{|c|c|c|c|c|c|c|c|}
\hline & $\mathrm{CM}$ & $\mathrm{AC}$ & HW & TB & OS & $\mathrm{BP}$ & Units \\
\hline \multicolumn{8}{|c|}{ Depth-integrated rates of solute production or consumption } \\
\hline DIRO & 25.0 & 23.6 & 7.7 & 13.2 & 0.2 & 14.4 & $\mathrm{mmol} \mathrm{m} \mathrm{d}^{-1}$ \\
\hline \multicolumn{8}{|c|}{ Pore water advection parameters } \\
\hline$\alpha_{o}$ & 0.56 & 0.98 & 0.27 & 0.76 & 0.02 & 1.0 & $d^{-1}$ \\
\hline$z_{1 / 2} \dagger$ & 5.5 & 5.1 & 8.6 & 11.2 & 13.7 & 4.7 & $\mathrm{~cm}$ \\
\hline \multicolumn{8}{|c|}{ Rates of sediment processest } \\
\hline$R_{\mathrm{cox}}$ & $25.4 \pm 0.6$ & $23.7 \pm 0.2$ & $7.7 \pm 0.8$ & $13.2 \pm 1.3$ & $0.2 \pm 0.1$ & $15.1 \pm 1.1$ & $\mathrm{mmol} \mathrm{m}^{2} \mathrm{~d}^{-1}$ \\
\hline$R_{\mathrm{CD}}$ & $25.8 \pm 1.0$ & $23.8 \pm 0.3$ & $7.7 \pm 0.8$ & $13.2 \pm 1.3$ & $0.3 \pm 0.1$ & $14.4 \pm 1.6$ & $\mathrm{mmol} \mathrm{m} \mathrm{d}^{-1}$ \\
\hline LAI & $1.9 \pm 0.1$ & $1.7 \pm 0.1$ & $0.5 \pm 0.03$ & $0.5 \pm 0.03$ & 0 & $0.9 \pm 0.08$ & \\
\hline
\end{tabular}

* The pore water advective velocity. On the basis of arguments presented in Boudreau (1997) this velocity was calculated as $\int \alpha_{z} \mathrm{~d} z=\frac{\alpha_{0}}{\beta}$.

$\dagger z_{1 / 2}$ is defined here as the advection half-depth, the sediment depth over which $\alpha_{z}$ decreases to half its value at the sediment surface (i.e., $\alpha_{o}$ ). On the basis of Eq, $3, z_{1 / 2}$ equals $\ln (2) / \beta$.

\$ Average values of $R_{\mathrm{cox}}$ and $R_{\mathrm{CD}}( \pm 1 \mathrm{SE})$ are based on the estimates of these quantities obtained with Eqs. 22 and 23.

$\S$ The absolute (and relative) flux of $\mathrm{O}_{2}$ into the sediments as a result of plant (sea grass) input, diffusion across the sediment-water interface, and advective input (modeled as nonlocal exchange). The plant input equals $\gamma \int P(z) \mathrm{d} z$ and was calculated as $0.4 \times \mathrm{LAI} \times 10.8 \mathrm{mmol} \mathrm{m}^{-2}$ leaf $\mathrm{d}^{-1}$ (see text for details). The diffusive $\mathrm{O}_{2}$ flux was calculated using Fick's first law modified for sediments (Burdige and Zimmerman 2002; Burdige 2006), with the gradient at the sediment-water interface determined using the first derivative of the sigmoid curve that was fit to each pore-water profile (see Eq. 14) evaluated at $z=0$. The advective input equals $\int \alpha_{z}\left(C-C_{o}\right) \mathrm{d} z$. The best-fit curve for the $\mathrm{O}_{2}$ data from each site was used in this calculation, along with the depth distribution of $\alpha_{z}$ (Eq. 3), and the integral was evaluated numerically using trapezoidal approximations.

Table 4. Model-derived results obtained with the LSI 7 pore water data.

\begin{tabular}{|c|c|c|c|c|c|c|c|}
\hline & $\mathrm{CM}$ & $\mathrm{AC}$ & HW & OS & $\mathrm{NC}$ & BB & Units \\
\hline \multicolumn{8}{|c|}{ Depth-integrated rates of production or consumption* } \\
\hline DIRO & 18.6 & 23.8 & 10.9 & 0.9 & 19.4 & 11.0 & mmol $\mathrm{m}^{2} \mathrm{~d}^{-1}$ \\
\hline DIRD & 36.7 & 47.6 & 21.8 & 1.8 & 39.8 & 22.1 & $\mathrm{mmol} \mathrm{m} \mathrm{d}^{-1}$ \\
\hline DIRA & 37.1 & 45.6 & 16.3 & 1.0 & 44.4 & 31.7 & $\mathrm{mmol} \mathrm{m} \mathrm{d}^{-1}$ \\
\hline \multicolumn{8}{|c|}{ Pore water advection parameters* } \\
\hline$\alpha_{o}$ & 0.53 & 1.94 & 0.49 & 2.04 & 1.28 & 0.80 & $\mathrm{~d}^{-1}$ \\
\hline$\beta$ & 0.13 & 0.2 & 0.02 & 0.36 & 0.21 & 0.07 & $\mathrm{~cm}^{-1}$ \\
\hline$v$ & 4.1 & 9.6 & 25.2 & 5.6 & 6.1 & 11.9 & $\mathrm{~cm} \mathrm{~d}^{-1}$ \\
\hline$z_{1 / 2}$ & 5.3 & 3.4 & 35.4 & 1.9 & 3.3 & 10.3 & $\mathrm{~cm}$ \\
\hline \multicolumn{8}{|c|}{ Rates of sediment processes* } \\
\hline$R_{\mathrm{COX}}$ & $18.5 \pm 0.1$ & $23.5 \pm 0.6$ & $10.0 \pm 1.6$ & $0.8 \pm 0.3$ & $20.3 \pm 1.6$ & $12.6 \pm 2.8$ & $\mathrm{mmol} \mathrm{m}^{2} \mathrm{~d}^{-1}$ \\
\hline$R_{\mathrm{CD}}$ & $18.4 \pm 0.2$ & $23.8 \pm 0.8$ & $10.9 \pm 2.3$ & $0.9 \pm 0.4$ & $19.4 \pm 2.3$ & $11.0 \pm 3.9$ & $\mathrm{mmol} \mathrm{m} \mathrm{d}^{-1}$ \\
\hline$L A I$ & $1.4 \pm 0.1$ & $1.5 \pm 0.1$ & $0.33 \pm 0.06$ & 0.0 & $1.3 \pm 0.06$ & $0.20 \pm 0.06$ & \\
\hline \multicolumn{8}{|c|}{ Sediment $\mathrm{O}_{2}$ input* } \\
\hline Plant & $6.1(64 \%)$ & $6.5(46 \%)$ & $1.4(16 \%)$ & $0(0 \%)$ & $5.8(54 \%)$ & $0.9(9 \%)$ & $\mathrm{mmol} \mathrm{m} \mathrm{m}^{-1}$ \\
\hline Diffusive & $0.3(3 \%)$ & $0.4(3 \%)$ & $0.01(<1 \%)$ & $0.01(1 \%)$ & $0.0002(<1 \%)$ & $0.04(<1 \%)$ & $\mathrm{mmol} \mathrm{m} \mathrm{d}^{-1}$ \\
\hline Advective & $3.2(33 \%)$ & $7.2(51 \%)$ & $7.4(84 \%)$ & $0.87(99 \%)$ & $4.9(46 \%)$ & $8.8(91 \%)$ & $\mathrm{mmol} \mathrm{m} \mathrm{d}^{-1}$ \\
\hline
\end{tabular}

\footnotetext{
* See Table 3 for abbreviations and definitions.
} 


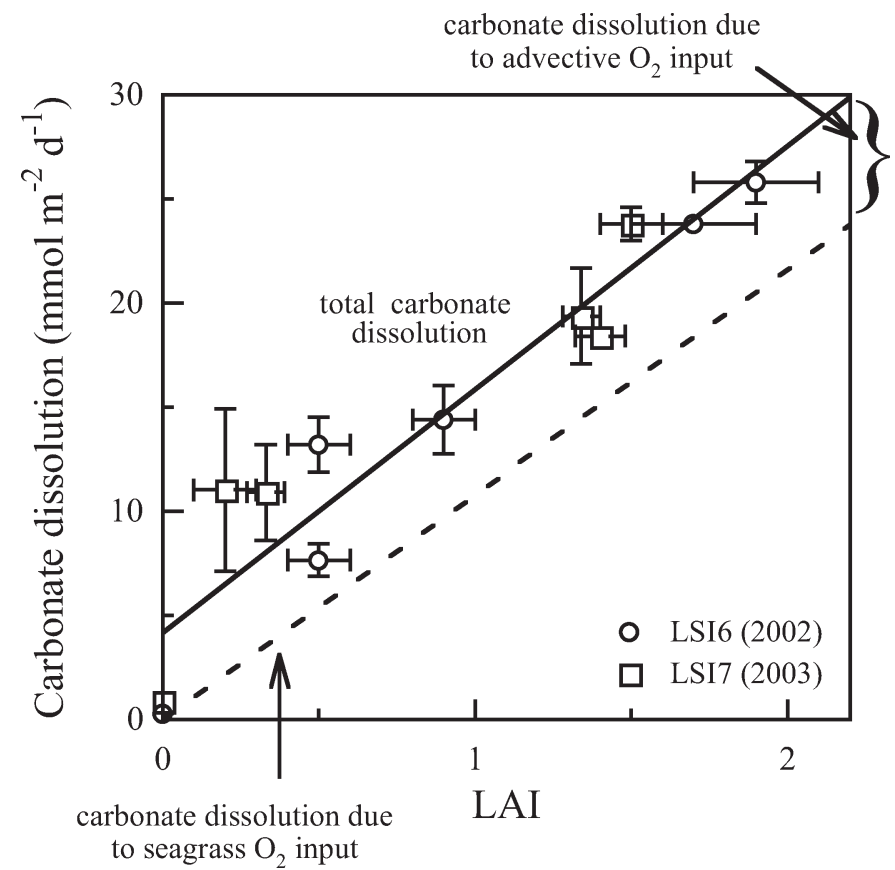

Fig. 6. The depth-integrated rate of carbonate dissolution $\left(R_{\mathrm{CD}}\right)$ versus LAI (error bars are standard errors). The solid line is the best-fit straight line through the data $\left(r^{2}=0.95, p<0.0001\right)$, while the dashed line can be thought of as the amount of carbonate dissolution that can be apportioned to belowground sea grass oxygen input. This rate scales linearly with LAI because of the way sea grass $\mathrm{O}_{2}$ input is parameterized (see the text for details). The difference between these two lines therefore represents carbonate dissolution driven by advective input of $\mathrm{O}_{2}$ into the sediments.

scope of this study, although ongoing work will allow us to examine these problems more critically (also see discussions in $\mathrm{Hu}$ 2007).

\section{Model results}

The role of sea grassses in sediment processes-Depthintegrated rates of carbonate dissolution $\left(R_{\mathrm{CD}}\right)$ in LSI sediments increased linearly with LAI (Fig. 6), although the rates of carbonate dissolution in LSI sediments are controlled by both belowground sea grass $\mathrm{O}_{2}$ input (as indicated by the dashed line in the figure) and advective $\mathrm{O}_{2}$ input (as indicated by the difference between this dashed line and the best-fit line through the data). Consistent with this observation, we have observed that if we increase or decrease the magnitude of the plant $\mathrm{O}_{2}$ input by a factor of two (i.e., if turtlegrasses transport $3 \%$ or $12 \%$, vs. $6 \%$, of their photosynthetically produced $\mathrm{O}_{2}$ belowground into the sediments), we obtain sediment carbonate dissolution rates that are roughly half or double the rates reported here.

Depth-integrated rates of sediment organic matter remineralization $\left(R_{\text {cox }}\right)$ show a similar relationship with LAI (not shown here) since the ratio $R_{\mathrm{CD}}: R_{\mathrm{cox}}$ is $1.03 \pm$ 0.10 for all of the profiles that were modeled. These results further demonstrate that the presence of sea grasses enhances both sediment carbonate dissolution and sedi- ment organic matter remineralization (see Yates and Halley 2006, who similarly observed that rates of carbonate dissolution increase with sea grass density in Florida Bay sediments). Of equal importance, the model results presented here allow us to close the oxygen and carbonate dissolution budgets at these sites (i.e., satisfy Eqs. 18-20) by incorporating the effects of advective pore-water exchange into a model of early diagenetic processes in these sediments.

Although the depth-integrated rate of turtlegrass belowground $\mathrm{O}_{2}$ input is well constrained (Bodensteiner 2006), the depth distribution in the sediments of this oxygen input, as defined by $P(z)$, is not as well defined. However, an examination of our model demonstrates that the model results should be largely independent of this depth distribution. To demonstrate this, we first note that regardless of how $P(z)$ is defined, its integrated value at a given site $[[P(z) \mathrm{d} z]$ is simply equal to the site LAI times the plant-specific belowground $\mathrm{O}_{2}$ input flux (here equal to $10.8 \mathrm{mmol} \mathrm{m}^{-2}$ leaf $\left.\mathrm{d}^{-1}\right)$, and is independent of the exact form of $P(z)$. Thus, if we integrate Eq. 13 we obtain,

$$
\begin{aligned}
\text { DIRO }= & \int R_{O}^{T}(z) \mathrm{d} z=\int D_{s} \frac{\partial^{2} O x}{\partial z^{2}} \mathrm{~d} z+\int P(z) \mathrm{d} z \\
& -\int\left[\left(\alpha_{o} e^{-\beta z}\right)\left(O x-O x_{o}\right)\right] \mathrm{d} z
\end{aligned}
$$

and note that the first and last integrals on the far right side of this equality (i.e., the diffusive and advective terms) are also independent of $P(z)$. Therefore, although DIRO (or either of the two depth-integrated solute production rates) depends on $\alpha_{o}$ and $\beta$ (as noted above), they should be largely independent of the exact form of $P(z)$.

In actuality, though, differences in the form of $P(z)$ do lead to differences in $\alpha_{o}$ and $\beta$, given the procedure used here to determine the best-fit values of $\alpha_{o}$ and $\beta$. However, these effects are small, and of secondary importance. To show this, the CM data from LSI 7 were fit with three different forms of $P(z)$, in addition to the one shown in Fig. 5, that all had the same depth-integrated value over the upper $20 \mathrm{~cm}$ of sediment. In one case, $P(z)$ was assumed to be constant over the entire $20 \mathrm{~cm}$; in a second case, all $\mathrm{O}_{2}$ input was assumed to occur between 4 and $5 \mathrm{~cm}$. In the third case, the $\mathrm{O}_{2}$ input was assumed to occur broadly between 1 and $9 \mathrm{~cm}$. The general shape and magnitude of this last sea grass $\mathrm{O}_{2}$ input curve largely matches that of the depth profile of the predicted rate of carbonate dissolution in these sediments, on the basis of the form of $P(z)$ determined using Fig. 5. In all four cases, depth-integrated rates and advection parameters determined by the model differed by less than 5\%, well within the estimated errors listed in Tables 3 and 4. Therefore, in the mass balance fit to the pore-water data using this inverse model the exact details of how $P(z)$ varies with depth does not significantly affect the magnitude of the depth-integrated rates calculated here.

Although these observations suggest that the specific form of $P(z)$ does not significantly affect the calculations presented here, there is still a need to better define the depth dependence of the belowground $\mathrm{O}_{2}$ input by sea grasses 
Table 5. A comparison of pore-water advection parameters.

\begin{tabular}{|c|c|c|c|}
\hline Location & Lee Stocking Island* & South Atlantic Bight U.S.A.† & Mid-Atlantic Bight U.S.A. \\
\hline Water depths & $2-10 \mathrm{~m}$ & $14-27 \mathrm{~m}$ & $15 \mathrm{~m}$ \\
\hline Current speeds§ & up to $60-100 \mathrm{~cm} \mathrm{~s}^{-1}$ & $2-45 \mathrm{~cm} \mathrm{~s}^{-1}$ & $\begin{array}{l}\text { up to } 70 \mathrm{~cm} \mathrm{~s}^{-1} \\
\text { (rarely }>30 \mathrm{~cm} \mathrm{~s}^{-1} \text { ) }\end{array}$ \\
\hline Sediment permeability & $>10^{-10} \mathrm{~m}^{2}$ (calc.) & $5 \times 10^{-11} \mathrm{~m}^{2}$ (meas.) & $\sim 2 \times 10^{-11} \mathrm{~m}^{2}$ (meas.) \\
\hline Sediment grain size & $200-800 \mu \mathrm{m}$ & $505 \mu \mathrm{m}$ (mean) & $400-500 \mu \mathrm{m}$ \\
\hline$\alpha_{o}$ & $0.02-2.0 \mathrm{~d}^{-1}\left(0.9 \mathrm{~d}^{-1}\right)$ & $0.3-2 \mathrm{~d}^{-1}$ & \\
\hline$v$ & $0.4-25.2 \mathrm{~cm} \mathrm{~d}^{-1}\left(8.1 \mathrm{~cm} \mathrm{~d}^{-1}\right)$ & & $\sim 0.2-2 \mathrm{~cm} \mathrm{~d}^{-1}$ \\
\hline$z_{1 / 2}$ & $1.9-35.4(9.0 \mathrm{~cm})$ & $\sim 2 \mathrm{~cm}$ & $\sim 0.6 \mathrm{~cm}$ \\
\hline
\end{tabular}

* The ranges of the LSI values of $\alpha_{o}, v$, and $z_{1 / 2}$ are based on results in Tables 3 and 4 , and the values in parentheses are the average values of these quantities.

$\dagger$ From Jahnke et al. (2005). Pore-water parameters were estimated by fitting pore-water profiles to an advection-diffusion reaction (ADR) equation similar to Eq. 5, although here $R(z)$ was estimated with parallel whole-sediment core incubations.

\$ From Reimers et al. (2004).

$\S$ The currents around LSI are largely tidally driven, and the values reported here are the peak values observed during each tidal cycle.

such as T. testudinum (for an ecological perspective of this problem see discussions in Jensen et al. 2005; Borum et al. 2006; Frederiksen and Glud 2006). From a geochemical perspective, a more accurate representation of $P(z)$ will be important in future versions of our model, in which the kinetics of biogeochemical processes occurring in these sediments are explicitly parameterized in the model (vs. the inverse approach taken here in which the model is used to determine the depth distribution of the rates of sediment processes).

Pore-water advection parameters - In sandy sediments in the South Atlantic Bight (SAB), Jahnke et al. (2005) used a slightly different modeling approach to estimate porewater advection rates in these permeable continental shelf sediments. As can be seen in Table 5, values of $\alpha_{o}$ and $z_{1 / 2}$ for LSI and SAB sediments are of the same order of magnitude. Estimates of the pore-water advection velocity $(v)$ in LSI sediments are also in reasonable agreement with directly measured velocities in mid-Atlantic Bight (MAB) permeable sediments (Reimers et al. 2004). The fact that the LSI pore-water advection parameters (particularly $v$ and $z_{1 / 2}$ ) may be slightly larger than similar values in SAB or MAB sediments could be due to several factors, including the higher permeability of LSI sediments, or faster bottom currents around the LSI sites.

Within the LSI data set, we also attempted to use simple correlative plots to further examine the environmental parameters that may control the magnitude of pore-water advection in these sediments (i.e., $\alpha_{\mathrm{o}}, \beta$, or $z_{1 / 2}$ vs., e.g., tidal current velocities or LAI). Unfortunately, these attempts were unsuccessful, and these plots showed no coherent trends. The complexity of this type of pore-water advection, and our incomplete understanding of the physical and biological processes affecting pore-water transport processes in permeable sediments, all likely contribute in some way to the lack of success of this relatively simple data analysis.

Sediment oxygen uptake-The results presented here allow us to examine the relationship between pore-water transport processes and oxygen uptake by permeable sea grass sediments. This is of some importance since oxygen uptake is an important biogeochemical process in marine sediments in general (e.g., Wenzhöfer and Glud 2002), and in sea grass sediments in particular (e.g., Jensen et al. 2005; Borum et al. 2006; Frederiksen and Glud 2006).

Diffusion accounts for $<5 \%$ (and oftentimes $<1 \%$ ) of the total oxygen uptake (TOU) by LSI sediments (see Figs. 7, 8, and Tables 3, 4). Sea grass $\mathrm{O}_{2}$ input to the sediment increases with increasing LAI, and scales linearly
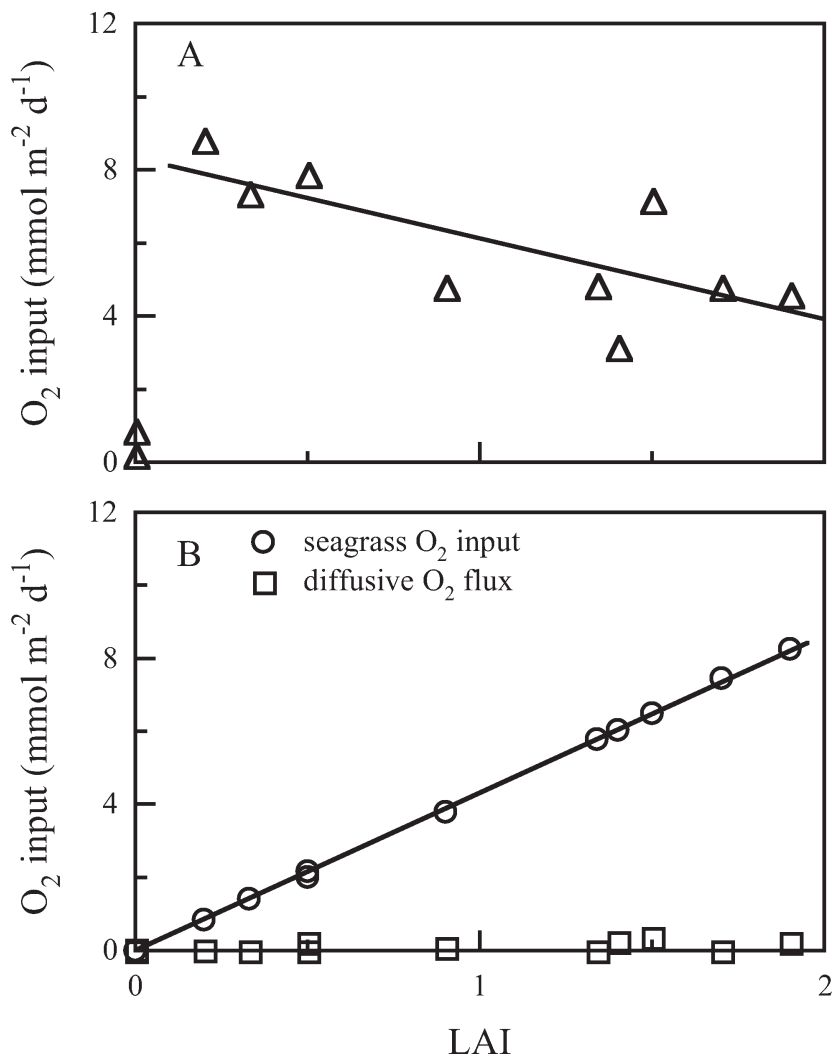

Fig. 7. Sediment $\mathrm{O}_{2}$ input versus LAI. (A) Oxygen input due to pore-water advective transport. Also shown here is the best-fit line $\left(r^{2}=0.54, p<0.05\right)$ through all of the data except that from the OS site (LAI $=0$; see the text for details). (B) Oxygen input due to belowground sea grass input (open circles) and diffusion across the sediment-water interface (open squares). All fluxes were calculated as described in the text (also see Tables 3,4). 


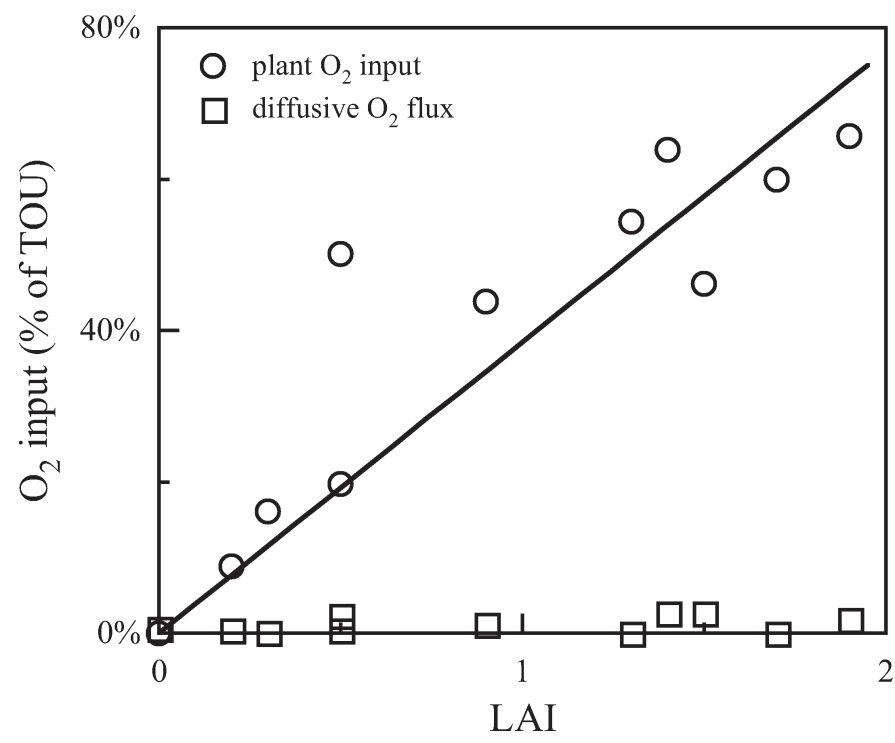

Fig. 8. The relative contributions of belowground sea grass $\mathrm{O}_{2}$ input (circles) and diffusive flux across the sediment-water interface (squares) to total sediment oxygen uptake (see Fig. 7 and Tables 3, 4 for the data used here). The straight line through the sea grass data is meant to illustrate the trends in the data and is not meant to imply any known functional relationship.

with LAI because of the way the process is parameterized (Fig. 7B). The relative importance of sea grass $\mathrm{O}_{2}$ pumping to TOU increases with LAI, and at moderate to high sea grass densities (LAI greater than $\sim 1$ ) it is the predominant mechanism by which oxygen is transported into LSI sediments (Fig. 8). In contrast, sea grass $\mathrm{O}_{2}$ pumping accounts for a minor fraction of the sediment oxygen uptake ( $\sim 10 \%$ or less) in temperate siliclastic sediments inhabited by Z. marina (Jensen et al. 2005; Frederiksen and Glud 2006). The reasons for these differences are not clear at the present time.
There is also a significant inverse relationship between sea grass density and model-derived advective $\mathrm{O}_{2}$ uptake by all LSI sediments except those at the OS site (see Fig. 7A). An examination of this observation suggests that the interplay of competing effects is likely important here. On the one hand, pore-water flow and advective exchange are driven by near-seabed pressure gradients produced by the interaction between bottom water flow and physical structures such as individual sea grass shoots or the sea grass canopy as a whole (or both) (e.g., see Koch et al. 2006 for a review). However, the sea grass canopy also attenuates horizontal flow through the canopy as one moves down through the canopy to the seafloor, the magnitude of which increases with shoot density (Peterson et al. 2004). Therefore as shoot density (i.e., LAI) increases, this latter effect appears to dampen pressure gradient or permeability effects that lead to advective exchange across the sediment-water interface. This explanation resembles the situation described in Koch and Gust (1999), in which they observed that the "skimming flow" over the sea grass canopy in a tidal-dominated system (such as that around LSI) decreased mixing between the bottom water in the canopy and that above the canopy.

As noted above, advective $\mathrm{O}_{2}$ uptake by the bare oolitic sands at the OS site is much lower than that predicted by the linear regression line through the results from the other sites (Fig. 7A). A possible explanation for this observation may be that the OS site is located in a high-energy region where migrating sand waves, or megaripples, occur (Boardman and Carney 1991; Dill 1991; Gonzalez and Eberli 1997). It is therefore a highly unstable (i.e., nonsteady-state?) site that may not necessarily be representative of more stable nonvegetated carbonate sediments on the Bahamas Bank.

\section{Rates of shallow-water sediment carbonate dissolution}

Depth-integrated carbonate dissolution rates (i.e., dissolution fluxes) estimated here with our inverse model are

Table 6. Shallow-water sediment carbonate dissolution and sediment carbonate budgets.

\begin{tabular}{lc}
\hline \hline & $\left(\mathrm{mmol} \mathrm{m}^{-2} \mathrm{~d}^{-1}\right)$ \\
\hline Global shallow water carbonate budget (Milliman 1993) & 13.6 \\
Gross production & 6.8 \\
$50 \%$ accumulation & 6.8 \\
$50 \%$ export (assumed) & $0.3-25.8$ \\
Bahamas Bank sediment carbonate dissolution fluxes (depth-integrated rates) & $\sim 2-6$ \\
Range on the basis of pore-water calculations (Fig. 6) & 8.6 \\
Core incubation* & $\sim 1-20$ \\
Regional estimate on the basis of the results in Fig. 6† & \\
Florida Bay carbonate dissolution fluxesł &
\end{tabular}

* Based on concentration changes versus time in incubated cores collected in January and May 2000 from intermediate-density sea grass bed sediments near LSI (D. Burdige unpubl. data). These rates were determined using procedures similar to those described by Jahnke et al. (2005). Assuming LAI values for these sites of $\sim 0.6$ (Burdige and Zimmerman 2002), these rates appear to be somewhat lower than the values shown in Fig. 6.

$\dagger$ Using a remote sensing algorithm for predicting sea grass density in optically shallow waters (Dierrsen et al. 2003), the analysis of SeaWifs imagery of the Bahamas Bank suggests that the average LAI of vegetated sediments on the Banks is $\sim 0.7$, and that the ratio of vegetated to nonvegetated sediments $(\mathrm{LAI}<0.1)$ is $\sim 1: 1$ (Dierssen and Zimmerman unpubl. data). Using these observations and the best-fit curve in Fig. 6 we can then scale up the calculated rates in Fig. 6 over the entire Bahamas Bank.

$\$$ From Walter and Burton (1990), Rude and Aller (1991), Ku et al. (1999), and Yates and Halley (2006). 

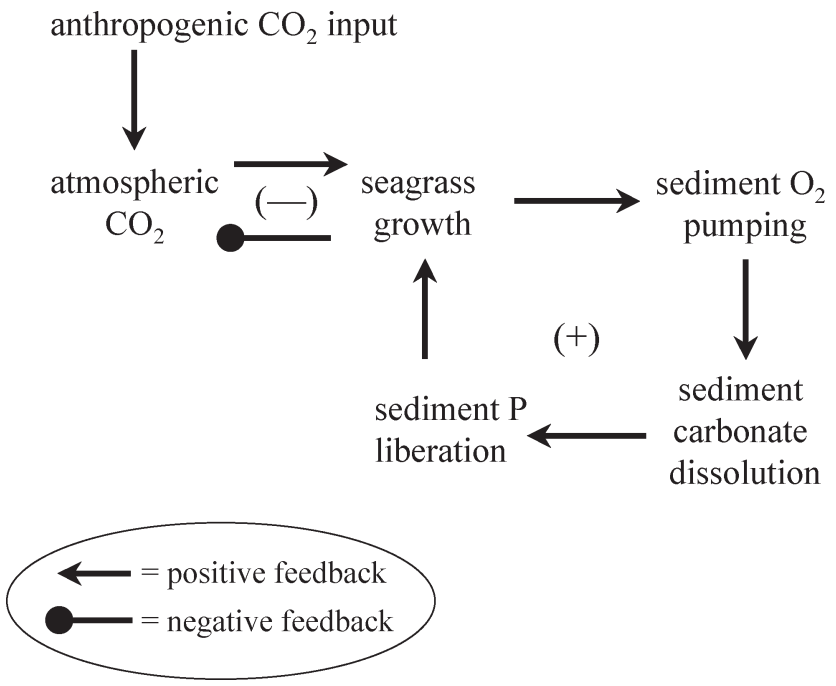

Fig. 9. A systems diagram illustrating the possible relationship between sea grass-mediated carbonate dissolution and rising atmospheric $\mathrm{CO}_{2}$. As is shown here, sea grass-mediated carbonate dissolution has the potential to act as a negative feedback to rising atmospheric $\mathrm{CO}_{2}$, although the magnitude of this effect remains to be quantified.

similar to values that are based on carbonate dissolution rates directly measured in LSI sediments (Table 6). Modelderived dissolution fluxes are also similar to fluxes determined in Florida Bay sediments. The relationship between $R_{\mathrm{CD}}$ and LAI in Fig. 6 also allows us to make a preliminary estimate of the carbonate dissolution flux for the entire Bahamas Bank by exploiting SeaWiFS remote sensing imagery and algorithms for predicting sea grass density in optically shallow waters (Dierssen et al. 2003). This approach yields a bankwide estimate of the carbonate dissolution flux that is comparable with the other dissolution fluxes reported in this table. Furthermore, this appears to be the case for oligotrophic Bahamas Bank sediments as well as more eutrophic (and anthropogenically affected) Florida Bay sediments.

The carbonate dissolution fluxes listed in Table 6 are also all of similar magnitude to estimates of global carbonate production, accumulation, or export fluxes for shallow water banks and bays (Milliman 1993). In deriving these estimates Milliman assumed that $50 \%$ of this carbonate production accumulates (is preserved) in bank and bay sediments, with the remaining material presumably being exported offshore (i.e., to the continental shelf, slope, or deep sea). However, as he notes, this preservation estimate is subject to large uncertainty; equally uncertain is the extent to which carbonate that does not accumulate in bank and bay sediments is indeed exported offshore, or actually undergoes in situ dissolution in these shallowwater sediments. Thus, on the basis of the results presented here, it appears that carbonate dissolution is an important loss term in the budget of shallow-water carbonate systems. Our results also suggest that carbonate dissolution, rather than offshore transport, may represent an important sink for gross shallow-water carbonate production (also see Yates and Halley 2006, who reached similar conclusions, on the basis of a very different approach, in their studies of Florida Bay sediments).

The regional dissolution flux estimated here for the Bahamas Bank will undergo continued refinement as we improve two key aspects of our work: estimates of carbonate dissolution rate as a function of environmental parameters such as LAI and sediment oxygen uptake, and the ability to obtain quantitative information about benthic habitats on the Bahamas Bank from remote sensing imagery. In particular, some areas on the Bank presently mapped as "sea grasses" may instead be dominated by grapestones or benthic algae (H. Dierrsen and R.C. Zimmerman unpubl. data). In this latter case, benthic primary production may contribute to the organic matter flux to the sediments, although it probably does not contribute to the belowground $\mathrm{O}_{2}$ flux needed to drive metabolic carbonate dissolution in the sediments.

If we assume a shallow-water carbonate dissolution flux of $8.6 \mathrm{mmol} \mathrm{m}^{-2} \mathrm{~d}^{-1}$ (Table 6) over the $\sim 800,000 \mathrm{~km}^{2}$ area of carbonate banks and bay sediments globally (Milliman 1993), then this translates into a global shallow-water dissolution rate of $2.5 \times 10^{12} \mathrm{~mol} \mathrm{yr}^{-1} \mathrm{C}$. For comparison, Andersson et al. (2003) used a physicalbiogeochemical box model to estimate a carbonate dissolution rate for shallow-water sediments of $11 \times 10^{12} \mathrm{mo}-$ $1 \mathrm{yr}^{-1} \mathrm{C}$. However, the bank and bay sediments we considered represent only $\sim 28 \%$ of the shallow-water sediments examined by these workers; when this is taken into account there is then very good agreement between the two results (i.e., $28 \%$ of $11 \times 10^{12} \mathrm{~mol} \mathrm{yr}^{-1} \mathrm{C}$ is $3.1 \times$ $\left.10^{12} \mathrm{~mol} \mathrm{yr}^{-1} \mathrm{C}\right)$.

Andersson et al. (2003) further concluded using their model that shallow-water sediments represent an insignificant buffer to rising atmospheric $\mathrm{CO}_{2}$. However, on the basis of our work we would like to suggest another possibility, not necessarily considered in their model, that has the potential to increase the importance of sea grass-dominated, shallow-water carbonate sediments as sites to mediate the rise in atmospheric $\mathrm{CO}_{2}$. Because sea grass photosynthesis is inherently $\mathrm{CO}_{2}$ limited (e.g., Zimmerman et al. 1997), sea grass productivity may increase in response to rising $\mathrm{CO}_{2}$ levels in the atmosphere and surface ocean (Palacios and Zimmerman 2007). Sea grass-mediated carbonate dissolution also liberates carbonate-bound phosphate (Jensen et al. 1998), which is a critical limiting nutrient in oligotrophic tropical environments such as the Bahamas Bank (e.g., Short et al. 1985; Fourqurean et al. 1992). This system therefore has important positive feedback characteristics since sea grass growth and the associated belowground $\mathrm{O}_{2}$ input enhances sediment carbonate dissolution, which then liberates phosphate from the sediments and promotes additional sea grass growth and carbonate dissolution (Fig. 9). Furthermore, because much of the organic matter remineralized in sea grass sediments is sea grass derived (Holmer et al. 2001; Hu and Burdige 2007), this dissolution represents a mechanism by which atmospheric $\mathrm{CO}_{2}$ is eventually transferred to the oceanic bicarbonate pool (see Eq. 1). Overall, this process will eventually exert a negative feedback on rising atmo- 
spheric $\mathrm{CO}_{2}$ levels (Fig. 9), although the magnitude of this effect remains to be quantified.

\section{References}

Andersson, A. J., F. T. Mackenzie, and L. M. Ver. 2003. Solution of shallow-water carbonates: An insignificant buffer against rising atmospheric $\mathrm{CO}_{2}$. Geol. 31: 513-516.

BenNeTt, R. H., AND OTHERS. 1990. In situ porosity and permeability of selected carbonate sediment: Great Bahama Bank Part 1: Measurements. Mar. Geotechnol. 9: 1-28.

Berner, R. A. 1966. Chemical diagenesis of some modern carbonate sediments. Am. J. Sci. 264: 1-36.

BoArdman, M. R., AND C. CARney. 1991. Origin and accumulation of lime mud in ooid tidal channels, Bahamas. J. Sediment. Petr. 61: 661-680.

Bodensteiner, L. E. 2006. The impact of light availability on benthic oxygen release by the seagrasses Thalassia testudinum (Banks ex König) and Zostera marina. M.S. thesis, San Jose State Univ.

Borum, J., K. Sand-Jensen, T. Binzer, O. Pedersen, and T. Greve. 2006. Oxygen movement in seagrasses, p. 255-270. In A. Larkum, R. Orth and C. Duarte [eds.], Seagrasses: Biology, ecology and conservation. Springer.

Boudreau, B. P. 1997. Diagenetic models and their implementation. Springer-Verlag.

, AND B. B. JøREGENSEN. 2001. The benthic boundary layer: Transport processes and biogeochemistry. Oxford Univ. Press.

— AND OThers. 2001. Permeable marine sediments, overturning an old paradigm. EOS 82: 133-136.

Broecker, W., C. Langdon, and T. TAKahashi. 2001. Factors controlling the rate of $\mathrm{CaCO}_{3}$ precipitation on Great Bahama Bank. Global Biogeochem. Cycles 15: 589-596.

Burdige, D. J. 2006. Geochemistry of marine sediments. Princeton Univ. Press.

-, W. M. Berelson, K. H. Coale, J. McManus, and K. S. JoHNSON. 1999. Fluxes of dissolved organic carbon from California continental margin sediments. Geochim. Cosmochim. Acta 63: 1507-1515.

—, AND R. C. Zimmerman. 2002. Impact of seagrass density on carbonate dissolution in Bahamian sediments. Limnol. Oceanogr. 47: 1751-1763.

Connell, E., T. Colmer, And D. Walker. 1999. Radial oxygen loss from intact roots of Halophila ovalis as a function of distance behind the root tip and shoot illumination. Aquat. Bot. 63: 219-228.

Crank, J. 1975. The mathematics of diffusion, 2nd ed. Clarendon Press.

Dierssen, H., R. Zimmerman, R. Leathers, T. Downes, and C. DAvis. 2003. Remote sensing of seagrass and bathymetry in the Bahamas banks using high resolution airborne imagery. Limnol. Oceanogr. 48: 444 455.

Dickson, A. G., J. D. Afghan, and G. C. Anderson. 2003. Reference materials for oceanic $\mathrm{CO} 2$ analysis: A method for the certification of total alkalinity. Mar. Chem. 80: 185-197.

Dill, R. F. 1991. Subtidal stromatolites, ooids and crusted-lime mud beds at the Great Bahama Bank Margin, p. 147-171. In From shoreline to abyss. SEPM Spec. Pub. No. 46.

Emerson, S., AND M. L. Bender. 1981. Carbon fluxes at the sediment-water interface: Calcium carbonate preservation. J. Mar. Res. 39: 139-162.

Fourqurean, J. W., J. C. Zieman, and G. V. N. Powell. 1992. Phosphorus limitation of primary productivity in Florida Bay: Evidence from $\mathrm{C}: \mathrm{N}: \mathrm{P}$ ratios of the dominant seagrass Thalassia testudinum. Limnol. Oceanogr. 37: 162-171.
Frederiksen, M. S., AND R. N. Glud. 2006. Oxygen dynamics in the rhizosphere of Zostera marina: A two-dimensional planar optode study. Limnol. Oceanogr. 51: 1072-1083.

Friedman, G. M., And J. E. Sanders. 1978. Principles of sedimentology. John Wiley \& Sons.

Gonzalez, R., And G. P. Eberli. 1997. Sediment transport and bedforms in a carbonate tidal inlet: Lee Stocking Island, Exumas, Bahamas. Sedimentology 44: 1015-1030.

Holmer, M., F. Ø. Andersen, S. L. Nielsen, and H. T. S. BoschKer. 2001. The importance of mineralization based on sulfate reduction for nutrient regeneration in tropical seagrass sediments. Aquat. Bot. 71: 1-17.

Hover, V. C., L. M. Walter, and D. R. Peacor. 2001. Early marine diagenesis of biogenic aragonite and Mg-calcite: New constraints from high-resolution STEM and AEM analyses of modern platform carbonates. Chem. Geol. 175: 221-248.

Hu, X. 2007. Seagrass-mediated carbonate dissolution and early diagenesis in Bahamas Bank sediments. Ph.D. dissertation, Old Dominion Univ.

- AND D. J. BuRDIGE. 2007. Enriched stable carbon isotopes in the pore waters of carbonate sediments dominated by seagrasses: Evidence for coupled carbonate dissolution and reprecipitation. Geochim. Cosmochim. Acta 71: 129-144.

Huettel, M., and I. T. Webster. 2001. Porewater flow in permeable sediments, p. 144-179. In B. P. Boudreau and B. B. Jørgensen [eds.], The benthic boundary layer. Oxford Univ. Press.

, W. Ziebis, AND S. Forster. 1996. Flow-induced uptake of particulate matter in permeable sediments. Limnol. Oceanogr. 41: 309-322.

Jahnke, R., M. Richards, J. Nelson, C. Roberton, A. Rao, and D. JAHNKE. 2005. Organic matter remineralization and porewater exchange rates in permeable South Atlantic Bight continental shelf sediments. Cont. Shelf Res. 25: 1433-1452.

Jensen, H. S., K. J. McGlathery, R. Marino, and R. W. HowARTH. 1998. Forms and availability of sediment phosphorus in carbonate sands of Bermuda seagrass beds. Limnol. Oceanogr. 43: 799-810.

Jensen, S. I., M. Kühl, R. N. Glud, L. B. Jørgensen, and A. Priemé. 2005. Oxic microzones and radial oxygen loss from roots of Zostera marina. Mar. Ecol. Prog. Ser. 293: 49-58.

Kanamori, S., And H. Inegami. 1980. Computer-processed potentiometric titration for the determination of calcium and magnesium in sea water. J. Oceanol. Soc. Jpn. 36: $177-184$.

Koch, E., And G. Gust. 1999. Water flow in tide- and wavedominated beds of the seagrass Thalassia testudinum. Mar. Ecol. Prog. Ser. 184: 63-72.

, J. D. Ackerman, J. J. Verduin, and M. van Keulen. 2006. Fluid dynamics in seagrass ecology - from molecules to ecosystems, p. 193-225. In A. Larkum, R. Orth and C. Duarte [eds.], Seagrasses: Biology, ecology and conservation. Springer.

Ku, T. C. W., L. M. Walter, M. L. Coleman, R. E. Blake, and A. M. Martini. 1999. Coupling between sulfur recycling and syndepositional carbonate dissolution: Evidence from oxygen and sulfur isotope compositions of pore water sulfate, South Florida Platform, USA. Geochim. Cosmochim. Acta 63: 2529-2546.

Lerman, A. 1979. Geochemical processes, water and sediment environments. John Wiley \& Sons.

Lohse, L., E. H. Epping, W. Helder, and W. van Raaphorst. 1996. Oxygen pore water profiles in continental shelf sediments of the North Sea: Turbulent vs. molecular diffusion. Mar. Ecol. Prog. Ser. 145: 63-75. 
Macintyre, I. G., And R. P. Reid. 1992. Comments on the origin of aragonite needle mud: A picture is worth a thousand words. J. Sediment. Petrol. 62: 1095-1097.

Marinelli, R. L., R. A. Jahnke, D. B. Craven, J. R. Nelson, and J. E. Eckman. 1998. Sediment nutrient dynamics on the South Atlantic Bight continental shelf. Limnol. Oceanogr. 43: 1305-1320.

Melim, L. A., H. Westphal, P. K. Swart, G. P. Eberli, and A. MunNeCKE. 2002. Questioning carbonate diagenetic paradigms: Evidence from the Neogene of the Bahamas. Mar. Geol. 185: 27-53.

Milliman, J. D. 1993. Production and accumulation of calcium carbonate in the ocean: Budget of a nonsteady state. Global Biogeochem. Cycles 7: 927-957.

Morse, J. W. 2003. Formation and diagenesis of carbonate sediments, p. 67-85. In F. T. Mackenzie [ed.], Treatise on geochemistry. Elsevier.

$\longrightarrow$, D. K. Gledhill, and F. J. Millero. 2003. $\mathrm{CaCO}_{3}$ precipitation kinetics in waters from the Great Bahama Bank: Implications for the relationship between Bank hydrochemistry and whitings. Geochim. Cosmochim. Acta 67: 2819-2862.

- J. J. Zulllig, L. D. Bernstein, F. J. Millero, P. Milne, A. Mucci, And G. R. Choppin. 1985. Chemistry of calcium carbonate-rich shallow water sediments in the Bahamas. Am. J. Sci. 285: 147-185.

, J. J. Zulllig, R. L. Iverson, G. R. Choppin, A. Mucci, And F. J. Millero. 1987. The influence of seagrass beds on carbonate sediments in the Bahamas. Mar. Chem. 22: 71-83.

Moulin, E., A. Jordens, And R. Wollast. 1985. Influence of the aerobic bacterial respiration on the early dissolution of carbonates in coastal sediments, 196-205, Progr. in Belgium Ocean. Res.

Palacios, S., And R. Zimmerman. 2007. Response of eelgrass (Zostera marina L.) to $\mathrm{CO}_{2}$ enrichment: Possible impacts of climate change and potential for remediation of coastal habitats. Mar. Ecol. Prog. Ser. 344: 1-13.

Peterson, P. H., R. A. J. Luettich, F. Micheli, and G. A. Skilleter. 2004. Attenuation of water flow inside seagrass canopies of differing structures. Mar. Ecol. Prog. Ser. 268: 81-92.

Press, W. H., S. A. Teukolsky, W. T. Vetterling, and B. P. FLANNERy. 2001. Numerical recipes in Fortran 77: The art of scientific computing, 2nd ed. Cambridge Univ. Press.

ReIMERs, C., AND OTHERs. 2004. In situ measurements of advective solute transport in permeable shelf sands. Cont. Shelf Res. 24: 183-201.
Rude, P. D., And R. C. Aller. 1991. Fluorine mobility during early diagenesis of carbonate sediments: An indicator of mineral transformations. Geochim. Cosmochim. Acta 55: 2491-2509.

Sand-Jensen, K., C. Prahl, and H. Stokholm. 1982. Oxygen release from roots of submerged aquatic macrophytes. Oikos 38: $349-454$.

Short, F. T., M. W. Davis, R. A. Gibson, and C. F. Zimmerman. 1985. Evidence for phosphorus limitation in carbonate sediments of the seagrass Syringodium filforme. Est. Coastal Shelf Sci. 20: 419-430.

Stephens, F. C., E. M. Louchard, R. P. Reid, and R. A. MAFFIONE. 2003. Effects of microalgal communities on reflectance spectra of carbonate sediments in subtidal optically shallow marine environments. Limnol. Oceanogr. 48: 535-546.

Walter, L. M., S. A. Bishop, W. P. Patterson, and T. W. Lyons. 1993. Dissolution and recrystallization in modern carbonates: Evidence from pore water and solid phase chemistry. Phil. Trans. R. Soc. Lond. A 344: 27-36.

- AND E. A. Burton. 1990. Dissolution of recent platform carbonate sediments in marine pore fluids. Am. J. Sci. 290: 601-643.

Webster, I. T. 2003. Wave enhancement of diffusivities within surficial sediments. Environ. Fluid Mech. 3: 269-288.

Wenzhöfer, F., And R. N. Glud. 2002. Benthic carbon mineralization in the Atlantic: A synthesis based on in situ data from the last decade. Deep-Sea Res. I 49: 1255-1279.

Wheatcroft, R. A. 2002. In situ measurements of near-surface porosity in shallow-water marine sands. IEEE J. Ocean Eng. 27: $561-570$.

Winland, H. D., And R. K. Matthews. 1974. Origin and significance of grapestone, Bahama Islands. J. Sed. Petrol. 44: $921-927$.

Yates, K. K., And R. B. Halley. 2006. Diurnal rates of calcification and carbonate sediment dissolution in Florida Bay. Est. Coasts 29: 24-39.

Ziebis, W., M. Huettel, and S. Forster. 1996. Impact of biogenic sediment topography on oxygen fluxes in permeable seabeds. Mar. Ecol. Prog. Ser. 140: 227-237.

Zimmerman, R. C., D. G. Kohrs, D. L. Stellar, and R. S. AlBerte. 1997. Impacts of $\mathrm{CO}_{2}$-enrichment on productivity and light requirements of eelgrass. Plant Physiol. 115: 599-607.

Received: 16 February 2007

Accepted: 18 September 2007 Amended: 15 October 2007 